\title{
Antioxidant Effects of Protocatechuic Acid and Protocatechuic Aldehyde: Old Wine in a New Bottle
}

\author{
Shijun Zhang $\mathbb{D}^{1},{ }^{1}$ Zhibo Gai, ${ }^{2}$ Ting Gui, ${ }^{2}$ Juanli Chen, ${ }^{3}$ Qingfa Chen $\mathbb{D}^{3},{ }^{3}$ and Yunlun Li $\mathbb{D}^{4,5}$ \\ ${ }^{1}$ First Clinical Medical College, Shandong University of Traditional Chinese Medicine, Jinan 250355, China \\ ${ }^{2}$ Key Laboratory of Traditional Chinese Medicine for Classical Theory, Ministry of Education, \\ Shandong University of Traditional Chinese Medicine, Jinan 250355, China \\ ${ }^{3}$ The Institute for Tissue Engineering and Regenerative Medicine, The Liaocheng University/Liaocheng People's Hospital, \\ Liaocheng, China \\ ${ }^{4}$ Innovation Research Institute of Traditional Chinese Medicine, Shandong University of Traditional Chinese Medicine, \\ Jinan 250355, China \\ ${ }^{5}$ The Third Department of Cardiovascular Diseases, Affiliated Hospital of Shandong University of Traditional Chinese Medicine, \\ Jinan 250355, China
}

Correspondence should be addressed to Qingfa Chen; tsingfachan@163.com and Yunlun Li; yunlun.lee@hotmail.com

Received 24 June 2021; Accepted 15 October 2021; Published 8 November 2021

Academic Editor: Fadia S. Youssef

Copyright $\odot 2021$ Shijun Zhang et al. This is an open access article distributed under the Creative Commons Attribution License, which permits unrestricted use, distribution, and reproduction in any medium, provided the original work is properly cited.

Phenolic compounds are naturally present as secondary metabolites in plant-based sources such as fruits, vegetables, and spices. They have received considerable attention for their antioxidant, anti-inflammatory, and anti-carcinogenic properties for protection against many chronic disorders such as neurodegenerative diseases, diabetes, cardiovascular diseases, and cancer. They are categorized into various groups based on their chemical structure and include phenolic acids, flavonoids, curcumins, tannins, and quinolones. Their structural variations contribute to their specific beneficial effects on human health. The antioxidant property of phenolic compounds protects against oxidative stress by up-regulation of endogenous antioxidants, scavenging free radicals, and anti-apoptotic activity. Protocatechuic acid (PCA; 3,4-dihydroxy benzoic acid) and protocatechuic aldehyde (PAL; 3,4-dihydroxybenzaldehyde) are naturally occurring polyphenols found in vegetables, fruits, and herbs. PCA and PAL are the primary metabolites of anthocyanins and proanthocyanidins, which have been shown to possess pharmacological actions including antioxidant activity in vitro and in vivo. This review aims to explore the therapeutic potential of PCA and PAL by comprehensively summarizing their pharmacological properties reported to date, with an emphasis on their mechanisms of action and biological properties.

\section{Introduction}

Polyphenols are natural compounds found abundantly in plant-based products that have been associated with potential beneficial effects on human health. They play a significant role in many physiological and metabolic processes [1], such as reducing the risk of various diseases including cardiovascular and neurodegenerative diseases, cancer, and diabetes $[2,3]$ in human beings. Protocatechuic acid (PCA; 3,4-dihydroxybenzoic acid) and protocatechuic aldehyde (PAL; 3,4-dihydroxybenzaldehyde) are the primary metabolites of complex polyphenols [3] present in vegetables, fruits, and herbs. PCA is a water-soluble benzoic acid derivative (Figure 1), reported to have anti-atherosclerotic, anti-inflammatory, antineoplastic, analgesic, antibacterial, hepatoprotective, and antiviral effects in both in vivo and in vitro studies [3-6]. It plays an important role in reversing the biochemical changes induced by cardiac dysfunction and diabetes [7] and reducing the metabolic disorders associated with obesity [8]. PAL-a natural, water-soluble phenolic aldehyde (Figure 1) - is also a naturally occurring compound resulting from phenolic acids' degradation [9]. PAL is reported to have antiadipogenic, anti-proliferative, and antiinflammatory properties both in vivo and in vitro [10-15]. 

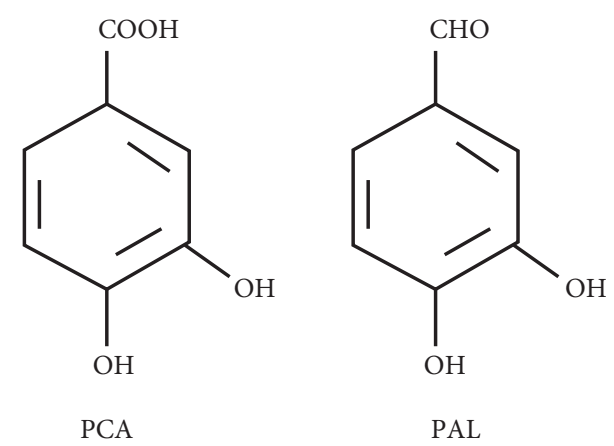

FIGURE 1: Chemical structure of protocatechuic acid (PCA) and protocatechuic aldehyde (PAL).

Recently, PCA and PAL have been confirmed to have antioxidant effects in many diseases, making these "old compounds" a potential "new application" for medical therapies. However, their antioxidant mechanisms are still not well understood [3]. Here, we aim to fill this gap in knowledge by reviewing the current studies on the antioxidative effects and the underlying mechanisms of these compounds in central nervous system-related diseases, cardiovascular diseases, diabetes, liver injury, cancer, obesity, and other diseases and discuss their potential in therapeutic applications.

\section{Source}

2.1. Sources of PCA and PAL in Nature. PCA and PAL are widely distributed in nature and are commonly found in vegetables, fruits, plant-derived beverages, and herbal medicines $[1,16]$. As shown in Table 1 , they are present in rice, crops, and legumes, such as colored rice bran, hemp, and lentils [17-21]. PCA is also found in kidney beans and mung beans [21]. The extract of onion bulbs' external dry layer has been demonstrated to contain quercetin and condensation products of PCA [22]. Basil (Ocimum basilicum), lemon thyme (Thymus citriodorus), and mint (Mentha $s p$.), belonging to the mint family, which are used as culinary herbs in many countries, contain many antioxidant and antiinflammatory phenolic compounds such as PCA and PAL among others [23-26]. Fruits and nuts such as friar plum, prune (Prunus domestica L.), grapes, gooseberry, currant, and Prunus persica var. platycarpa (Tabacchiera peach) also contain PCA and PAL [27-31]. PCA can also be extracted from dried almond hulls (Prunus amygdalus Batsch) [32]. Cocoa beans contain 15 phenolic compounds including PCA and PAL [33]. The plant- and fruit-derived products such as barley tea, hot and cold Hibiscus sabdariffa L. (Hs, roselle; Malvaceae) beverages [34-37], the crude oil extracted from acai berries (Euterpe oleracea) [38], and cultivated Emblica wine [39], and red wine [40] were also found to contain PCA and PAL. The medicinal plants used in traditional Chinese medicines (TCMs) contain the bioactive components PCA and PAL. Ginkgo biloba L [41-43] and Hypericum perforatum [44] contain PCA; Pinellia ternata [45] and Lilium lancifolium [46] contain PAL. Some TCMs such as Cynomorium songaricum Rupr., [47] and the fruiting body of Phellinus linteus [48] contain both PCA and PAL. The most famous and one of the most frequently used TCMs is Salvia miltiorrhiza (SM), known as Danshen in Chinese. It contains various phenolic acids and diterpenoids, with relatively higher amounts of PCA $1.43 \mathrm{mg} / \mathrm{g}$ and PAL $1.73 \mathrm{mg} / \mathrm{g}$ [49]. It has been proved that PAL is an active component of SM and the main degradation product of its water-soluble active component-Salvianolic acid B [50]. The amount of PCA and PAL varies based on the plant part; for example, $0.832 \mathrm{mg} / \mathrm{kg}$ fresh weight of PCA is present in Alpinia oxyphylla (AOF) fruit, while about $11.3 \mathrm{mg} / \mathrm{kg}$ is found in its air-dried kernels [51, 52].

2.2. Sources of PCA and PAL by Metabolism. Gluten-free flours, nuts, fruits, and red wine contain not only dietary antioxidants, such as phenolic acids, flavonoids, and anthocyanins, as has already been described, but they are among the richest food source of bioactive polyphenols (e.g., ellagitannins and proanthocyanidins) [53-55]. Anthocyanins are considered to be the most potent antioxidants among flavonoids [56], and PCA and PAL are the primary metabolites of the complex antioxidant polyphenols, anthocyanins, and proanthocyanidins $[53,54,57]$. The fate of dietary polyphenols was investigated using a simulated in vitro intestinal fermentation system. The food delivers polyphenols to the gastric and intestinal. Digestions do affect the polymeric fractions. The biotransformation of polymerized polyphenols (by gut microbiota) into lower molecular weight compounds, such as caffeic acid, PAL, and PCA, depends on the intestinal phase $(\mathrm{pH}$ 6.7-7.4) [53-55]. After absorption, they pass into the bloodstream and are then distributed to the organs, including the brain, to exert their pharmacological and biological effects (Figure 2) [57]. Pharmacokinetic analysis using LC-MS-MS showed that after oral and intravenous administration of PAL into Wistar rats, PAL was extensively metabolized to PCA in the plasma of the rats via oxidation pathways $[58,59]$. It was found in the plasma in the form of PAL, PCA, and their conjugates, and the conjugates were detected in the intestine, liver, and kidney. PAL was methylated in the liver, oxidized to PCA, and excreted via urine and bile. A part of the glucuronide conjugates of PAL and PCA excreted into the bile might be converted again to PAL and PCA and reabsorbed in the intestine (Figure 2) [58, 59].

\section{Mechanism of Antioxidant Effects}

Oxidative stress results from the buildup of reactive oxygen species (ROS) or free radicals, which are the by-products of metabolic processes, and are implicated in the pathogenesis of various diseases including cardiovascular diseases, diabetes, cancer, and neurodegenerative diseases. The antioxidants function through direct or indirect mechanisms including scavenging of ROS and intracellular enzymatic reactions [90]. As they are redox-active with a short life span and are sacrificed when they act on the ROS, they need to be regenerated to curtail the ROS levels. An indirect antioxidant effect can trigger the host cells' self-defense 
TABLE 1: Sources of PCA and PAL in nature and their biological activities.

\begin{tabular}{|c|c|c|c|c|c|}
\hline No. & Biological source & $\begin{array}{l}\text { PCA content } \\
\text { (ug/g) }\end{array}$ & $\begin{array}{l}\text { PAL content } \\
\text { (ug/g) }\end{array}$ & Biological activity & References \\
\hline 1 & Rice & $23.2-1043(\mathrm{DW})$ & $2-188(\mathrm{DW})$ & $\begin{array}{l}\text { Antioxidative, anti-inflammatory } \\
\text { chemoprevention }\end{array}$ & {$[18,60,61]$} \\
\hline 2 & Buckwheat (Fagopyrum esculentum) & $6.61-24.5(\mathrm{DW})$ & $3.65-19.74(\mathrm{DW})$ & Antioxidative & {$[21,62]$} \\
\hline 3 & Green pea (Pisum sativum) & $1.26-11.38(\mathrm{DW})$ & $0.07-0.12(\mathrm{DW})$ & Antioxidative & {$[21,63]$} \\
\hline 4 & Fava bean (Vicia faba) & $0.61-2.42(\mathrm{DW})$ & $0.68-5.63(\mathrm{DW})$ & NT & {$[21]$} \\
\hline 5 & Hemp (Cannabis sativa) & $5.63-22.06(\mathrm{DW})$ & $6.41-34.77(\mathrm{DW})$ & NT & {$[21]$} \\
\hline 6 & Lupin (Lupinus albus) & $0.15 \pm 0.02(\mathrm{DW})$ & ND & NT & [21] \\
\hline 7 & Wheat & $0.07-0.11(\mathrm{DW})$ & $0.19 \pm 0.04(\mathrm{DW})$ & Antioxidative & {$[21]$} \\
\hline 8 & Lentils & $\begin{array}{l}20.28-37.72 \\
\quad(\mathrm{DW})\end{array}$ & $3.69-12.14(\mathrm{DW})$ & Antioxidative, anti-inflammatory & {$[20]$} \\
\hline 9 & Commercial black-colored cowpeas & $18.97 \pm 0.45(\mathrm{DW})$ & NT & Antioxidative antidiabetic & [64] \\
\hline 10 & Pea (Pisum sativum L.) varieties & $12.1-163.5(\mathrm{DW})$ & NT & $\begin{array}{l}\text { Antioxidative, anti-inflammatory } \\
\text { immunomodulation }\end{array}$ & {$[65]$} \\
\hline 11 & Common beans & $\begin{array}{l}95.34-253.42 \\
(\mathrm{DW})\end{array}$ & NT & Antioxidative & {$[66]$} \\
\hline 12 & Onion (Allium cepa L.) & $1027(\mathrm{DW})$ & NT & Antioxidative, antimutagenic & {$[22]$} \\
\hline 13 & Mint family plants & $\mathrm{UC}(\mathrm{FW})$ & $\begin{array}{l}0.843-18.285 \\
\quad(\mathrm{FW})\end{array}$ & Antioxidative, anti-inflammatory & [26] \\
\hline 14 & $\begin{array}{c}\text { Yayla Cayi (Thymus praecox OPIZ subsp. } \\
\text { Grossheimii (Ronniger) Jalas) }\end{array}$ & $\mathrm{UC}(\mathrm{DW})$ & $\mathrm{UC}(\mathrm{DW})$ & Antioxidative & {$[67]$} \\
\hline 15 & Loquat (Eriobotrya japonica L.) & $\begin{array}{l}0.843-18.285 \\
\quad(\mathrm{DW})\end{array}$ & NT & Antioxidative & {$[68]$} \\
\hline 16 & Kinnow peel & $177(\mathrm{DW})$ & NT & Antioxidative, health benefits & [69] \\
\hline 17 & Banana pulp & $340(\mathrm{DW})$ & NT & Antioxidative, health benefits & [69] \\
\hline 18 & Prune (Prunus domestica L.) & $355.87(\mathrm{FW})$ & NT & Antioxidative & {$[27]$} \\
\hline 19 & Friar plum (Prunus salicina Lindl.) & $50-160(\mathrm{FW})$ & NT & $\begin{array}{c}\text { Antioxidative, increased edible } \\
\text { quality }\end{array}$ & {$[28]$} \\
\hline 20 & $\begin{array}{c}\text { Prunus persica var. platycarpa (Tabacchiera } \\
\text { peach) }\end{array}$ & $0.19(\mathrm{FW})$ & $0.02(\mathrm{FW})$ & Antioxidative & {$[31]$} \\
\hline 21 & Currant (Ribes L.) & $137.6-464.8(\mathrm{FW})$ & NT & Antioxidative & {$[30]$} \\
\hline 22 & Gooseberry (Ribes uva-crispa L.) & $24.7-77.7(\mathrm{DW})$ & NT & Antioxidative & {$[30]$} \\
\hline 23 & Grapes & $0.143-0.371(\mathrm{FW})$ & NT & Antioxidative & [29] \\
\hline 24 & Acai (Euterpe oleracea Mart.) seed & $106-843(\mathrm{DW})$ & NT & $\begin{array}{l}\text { Antioxidative, antimalarial, } \\
\text { antiplasmodial }\end{array}$ & {$[70]$} \\
\hline 25 & Cocoa beans & $\begin{array}{l}197.9-385.3 \\
(\mathrm{DW})\end{array}$ & 2.6-1945.7 (DW) & Antioxidative, anti-inflammatory & {$[33]$} \\
\hline 26 & Almonds (Prunus amygdalus Batsch) & $66.67(\mathrm{DW})$ & NT & Antioxidative & {$[71]$} \\
\hline 27 & Pecan (Carya illinoinensis) & $13.1-30.5(\mathrm{FW})$ & UC & Antioxidative & {$[72]$} \\
\hline 28 & $\begin{array}{c}\text { Orobanche cernua Loefling } \\
\text { (Orobanchaceae) }\end{array}$ & NT & $0.353(\mathrm{FW})$ & Anticancer & {$[73]$} \\
\hline 29 & Salvia miltiorrhiza & $56 \sim 152(\mathrm{DW})$ & $59 \sim 94(\mathrm{DW})$ & Antioxidative, anti-inflammatory & [49] \\
\hline 30 & The fruiting body of Phellinus linteus & $10(\mathrm{FW})$ & $9(\mathrm{FW})$ & Aldose reductase inhibitors & {$[48]$} \\
\hline 31 & Ginkgo biloba L. leaf & $\begin{array}{l}2708 \sim 345321 \\
\quad(\mathrm{FW})\end{array}$ & NT & Antioxidative & {$[42,43]$} \\
\hline 32 & $\begin{array}{l}\text { Aesculus hippocastanum } \\
\text { L. (Hippocastanaceae) }\end{array}$ & $72.53(\mathrm{DW})$ & NT & Antioxidative & {$[44]$} \\
\hline 33 & Hypericum perforatum & $761.67(\mathrm{DW})$ & NT & $\begin{array}{c}\text { Antioxidative, anti-inflammatory, } \\
\text { antigenotoxic }\end{array}$ & {$[44]$} \\
\hline 34 & $\begin{array}{c}\text { Alpinate oxyphyllae fructus (Alpinia } \\
\text { oxyphylla MIQ, AOF) }\end{array}$ & $\begin{array}{c}0.832(\mathrm{FW}), 8.5 \\
(\mathrm{DW})\end{array}$ & NT & $\begin{array}{l}\text { Antioxidative, anti-cell migration, } \\
\text { antiapoptosis }\end{array}$ & {$[51,74]$} \\
\hline 35 & $\begin{array}{c}\text { Schisandra chinensis (Turcz.) Baill. fructus } \\
\text { (SCF) }\end{array}$ & $210(\mathrm{DW})$ & NT & $\begin{array}{l}\text { Antioxidative, anti-beta amyloid } \\
\text { formation }\end{array}$ & {$[75,76]$} \\
\hline 36 & Ramulus Cinnamomi & $\begin{array}{l}61.5 \sim 137.7 \\
\quad(\mathrm{DW})\end{array}$ & NT & Antioxidative & {$[77]$} \\
\hline 37 & Cinnamon fruits & $54.7(\mathrm{DW})$ & NT & Antioxidative & {$[78]$} \\
\hline 38 & Lilium lancifolium & $\begin{array}{l}0.5937 \sim 2.962 \\
(\mathrm{DW})\end{array}$ & NT & Antioxidative & {$[46]$} \\
\hline 39 & Cynomorium songaricum Rupr. & $148(\mathrm{DW})$ & $0.629(\mathrm{DW})$ & $\begin{array}{c}\text { Phytoestrogenic- or } \\
\text { phytoandrogenic-like activities }\end{array}$ & {$[47]$} \\
\hline
\end{tabular}


TABLE 1: Continued.

\begin{tabular}{|c|c|c|c|c|c|}
\hline No. & Biological source & $\begin{array}{l}\text { PCA content } \\
(\mathrm{ug} / \mathrm{g})\end{array}$ & $\begin{array}{l}\text { PAL content } \\
(\mathrm{ug} / \mathrm{g})\end{array}$ & Biological activity & References \\
\hline 40 & The fruiting bodies of Ganoderma lucidum & NT & $0.952(\mathrm{DW}) ?$ & Aldose reductase inhibitors & [79] \\
\hline 41 & Pinellia ternata & NT & UC & $\begin{array}{l}\text { Antioxidative, change of activity of } \\
\text { protective enzyme }\end{array}$ & {$[45,80]$} \\
\hline 42 & Prunella vulgaris & $\begin{array}{c}0.0089 \sim 0.0476 \% \\
(\mathrm{w} / \mathrm{w})\end{array}$ & $\begin{array}{l}0.003 \sim 0.008 \% \\
(\mathrm{w} / \mathrm{w})\end{array}$ & Antioxidative & [81] \\
\hline 43 & Black cohosh (Actaea racemosa L.) & $8.8(\mathrm{DW})$ & $4.6(\mathrm{DW})$ & Antioxidative, anticancer & [82] \\
\hline 44 & Rattan materials (Calamoideae faberii) & $14 \sim 97(\mathrm{DW})$ & $18 \sim 99(\mathrm{DW})$ & Antioxidative & {$[83]$} \\
\hline 45 & Leaves of Lycium barbarum & NT & $\begin{array}{l}0.87 \sim 9.47 \\
\quad(\mathrm{DW})\end{array}$ & Antioxidative & {$[84,85]$} \\
\hline 46 & $\begin{array}{l}\text { Hydnophytum formicarum Jack. } \\
\text { (Rubiaceae) }\end{array}$ & NT & $1.5(\mathrm{DW})$ & Antioxidative, antimicrobial & {$[86]$} \\
\hline 47 & $\begin{array}{c}\text { Hibiscus sabdariffa L. (Hs, Roselle; } \\
\text { Malvaceae) }\end{array}$ & $94.1(\mathrm{DW})$ & NT & $\begin{array}{c}\text { Antioxidative, anti-inflammatory, } \\
\text { antiurease }\end{array}$ & {$[87,88]$} \\
\hline 48 & Echinacea (Echinacea purpurea) & UC & $\mathrm{UC}$ & Antioxidative, anti-inflammatory & {$[67]$} \\
\hline 49 & Green tea (Camellia sinensis) & UC & UC & Antioxidative, anti-inflammatory & {$[67]$} \\
\hline 50 & Barley tea & NT & $2.6(\mathrm{DW})$ & Antioxidative, anti-inflammatory & [89] \\
\hline 51 & Grape wine & $0.7 \sim 5.24 \mathrm{mg} / \mathrm{L}$ & NT & Antioxidative, anti-inflammatory & {$[39,40]$} \\
\hline 52 & Olive oil (Olea europaea) & $176.08(\mathrm{DW})$ & NT & Antioxidative, anti-inflammatory & {$[44]$} \\
\hline
\end{tabular}

DW, dry weight; FW, fresh weight; ND, not detected (i.e., below the detection level); NT, not tested; UC, detected, but content unclear.<smiles>[R20]c1cc(-c2[o+]c3cc(O)cc(O)c3cc2OC2O[C@H](CO)[C@@H](O)[C@H](O)C2O)cc(O)c1O</smiles>

Anthocyanidin
Hydrolysis of glycoside linkage

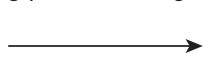<smiles>[R10]Oc1cc(-c2[o+]c3cc(O)cc(O)c3cc2O)cc(O[GaH])c1O</smiles>

Degradation in the intestine at $\mathrm{pH} 7-8$
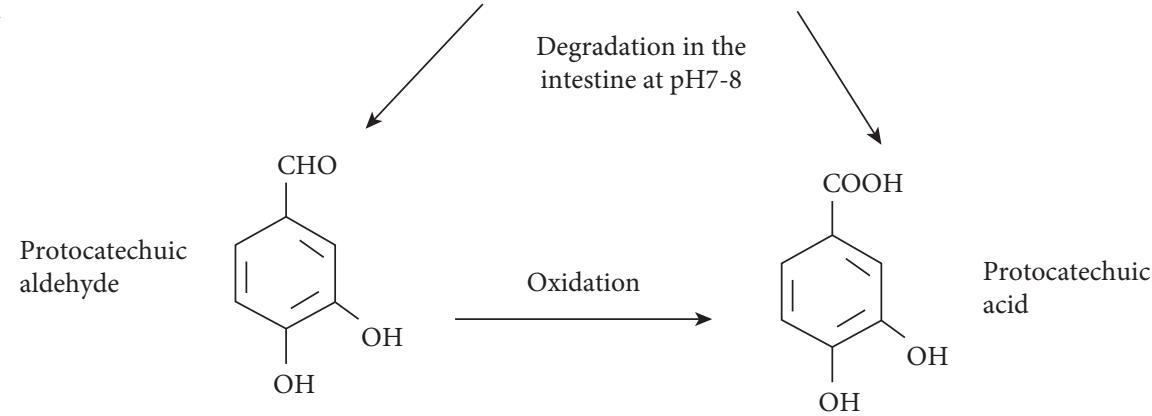

FIgure 2: Anthocyanins metabolism into PCA and PAL. A generic anthocyanin with a glucoside moiety is pictured. Parent anthocyanin species are first converted to an aglycon (anthocyanidin) form by hydrolysis of glycoside linkages in the small intestine. PAL could be oxidized to PCA in the intestine.

mechanisms to fight oxidative stress. Mitochondria are also morphologically and functionally altered, leading to excessive ROS formation and decrease in energy due to the reduction in ATP production, alteration of calcium homeostasis, and apoptosis induction [91]. The antioxidant potential of PCA and PAL by increasing the activity of endogenous antioxidant enzymes glutathione peroxidase (GSH-PX) and superoxide dismutase (SOD) has been reported in recent studies. PCA is also regarded as the perfect peroxyl radical scavenger in the polar environment of aqueous solutions and a relatively good anti-radical protector in nonpolar environment of lipid solutions [92]. It is capable of attenuating oxidative stress by increasing the activity of GSH-PX and SOD, as well as reducing the activity of xanthine oxidase (XOD) and NADPH oxidase (NOX) and the concentrations of malondialdehyde (MDA) [5, 93]. PAL was reported to inhibit the production of ROS in rat PC12 cells and human SH-SY5Y cells [94, 95]. Tables 2 and 3 
provide details of the in vitro and in vivo antioxidant effects of PCA and PAL. Figure 3 illustrates the antioxidant mechanisms of the 2 metabolites through activation of multiple transcription factors in different cells, tissues, and organs.

3.1. Antioxidant Properties in Central Nervous System Diseases. Nerve cells in the brain are metabolically active and vulnerable to injury caused by excessive ROS generation or impairment of the antioxidant defense system, which results in neurodegenerative diseases and brain disorders [96-98]. The antiaging, antioxidant, and antiinflammatory properties of PCA and PAL have been extensively studied in neurodegenerative diseases including Parkinson's disease (PD) and Alzheimer's disease (AD) [3, 4, 99-101], brain injury diseases such as intracerebral hemorrhage (ICH) and cerebral ischemia-reperfusion $[104,105]$, as well as in depression [106], diabetes-induced oxidative stress in the brain [107], and cadmium (Cd)-induced cortical toxicity [108], in vitro and in vivo.

3.1.1. Neurodegenerative Diseases. Neurodegenerative diseases, including Alzheimer's disease (AD) and Parkinson's disease (PD), have common characteristics consisting of progressive neuronal loss and impaired neuronal function. Oxidative damage, mitochondrial dysfunction, and neuroinflammation are strongly implicated in the pathogenesis of these diseases, which require early intervention to reduce the risks due to the lack of clinically relevant drugs. In the recent times, the use of natural products for the prevention of these diseases has gained importance due to their neuroprotective properties, such as antioxidation and antiinflammation effects [109]. PCA has the potential to counter oxidative stress, excitotoxicity, and neuroinflammatory and nitrosative stress effects [110]. It has been shown to significantly reduce neurodegeneration and locomotor deficits in an MPTP-induced PD mouse model. Several mechanisms may be relevant for bringing about the protective effects. PCA has been reported to increase the nuclear factor erythroid 2-related factor 2 (Nrf2) protein expression and transcription activity; modulate the cellular redox status with the upregulated expression of hallmark antioxidant enzymes, including heme oxygenase-1(HO-1), SOD, and catalase (CAT); and decrease the levels of MDAtreated PC12 cells [102]. Treatment with PCA also inhibited the activation of nuclear factor- $\mathrm{kb}(\mathrm{NF}-\mathrm{\kappa B})$ and expression of inducible nitric oxide synthase (iNOS) [102]. PCA effectively suppressed palmitic acid (PA)-induced ROS generation and reversed the PA-impaired proliferation of neural stem/progenitor cells (NSPCs) [111, 112]. Furthermore, it demonstrated significant therapeutic effects in preclinical animal models with neurodegenerative diseases such as $\mathrm{AD}, \mathrm{PD}$, and $\mathrm{D}$-galactose-induced accelerated aging, in vivo $[110,113,114]$. It could also inhibit the oxidative damage induced by hydrogen peroxide $\left(\mathrm{H}_{2} \mathrm{O}_{2}\right)$ through the suppression of LDH release, caspase- 3 activity, and Bax expression, as well as induction of mitochondrial membrane potential and $\mathrm{Bcl}-2$ expression in cultured retinal ganglion cells (RGC-5) [115]. In cellular models of PD, PAL markedly increased the cell viability rates and mitochondrial oxidation-reduction activity and membrane potential and reduced the intracellular ROS levels in PC12 cells [100]. In animal models of PD, PAL improved specific behavioral defects caused by 6-OHDA and MPTP through its neuroprotective pharmacological effects. The potential mechanisms may be related to the upregulation of the DJ-1 protein, decrease in $\alpha$-synuclein, and its growth-promoting effect on the spine density [100]. PAL could also prevent the tyrosine hydroxylase (TH)-positive dopaminergic neuron loss through induction of DJ-1 and inhibition of $\alpha$-synuclein expression. It also restored oxidative stress-induced inactivation of the Akt pathway and suppressed excessive $\mathrm{H}_{2} \mathrm{O}_{2}$-induced DJ-1 oxidation in SH-SY5Y cells [92]. Posttreatment of PAL in the mouse model of PD showed that it improved the behavioral deficits and protected against dopaminergic neuronal loss [101]. PAL mediated polo-like kinase 2 (PLK2) expression, which upregulated glycogen synthase kinase $3 \beta$ (GSK3 $\beta$ ) phosphorylation and Nrf2 nuclear translocation, improved mitochondrial dysfunction, and attenuated oxidative stress injury, which resulted in effective neuroprotection [101]. PCA from Alpinia oxyphylla protected PC12 cells against apoptosis and oxidative stress induced by rotenone by decreasing mitochondrial dysfunction [116]. It reversed the cognitive deficits by inhibiting amyloid deposits and inflammatory response in aged $\mathrm{A} \beta \mathrm{PP} / \mathrm{PS} 1$ double transgenic mice and also recovered the mitochondrial function to counteract the ROS generation in $\mathrm{AD}$ [114].

3.1.2. Brain Injury Diseases. PCA had antiapoptotic and antiinflammatory effects and induced antioxidative stress in animal models with intracerebral hemorrhage (ICH) or cerebral ischemia. It improved the endogenous antioxidant defense system by downregulating the P38/JNK-NF- $\kappa \mathrm{B}$ pathway in an ICH mouse model and in a rat model of cerebral ischemia [117]. It also attenuated the protein and gene expression of TNF- $\alpha$, IL- $1 \beta$, and IL- 6 in vivo [105]. A single dose of 5 and $10 \mathrm{mg} / \mathrm{kg}$ PCA intraperitoneal injection (i.p.) for 7 days in aged rats remarkably led to the induction of CAT and GSH-PX antioxidant activities and suppression of oxidative stress [118]. In experimentally developed chronic intermittent hypoxia rat models, PCA reversed the neurocognitive function impairment through modulation of synaptic plasticity, inhibition of ROS production, and neuronal apoptosis, as well as induction of glial cell proliferation and brain-derived neurotrophic factor (BDNF) expression [93]. Ischemia-induced oxidative stress, activation of astrocytes and microglia, neuronal cell death, bloodbrain-barrier (BBB) disruption, and reduction in glutathione (GSH) concentration were reversed by administration of PCA in hippocampal neurons [16]. Seizure-induced hippocampal neuronal death was also inhibited by PCA treatment [119]. PAL too has been reported to protect against cerebral oxidative injury induced by ischemiareperfusion (I/R) syndrome through $\mathrm{PKC} \varepsilon / \mathrm{Nrf} 2 / \mathrm{HO}-1$ pathway [104]. 
TABle 2: Summary of the effects on antioxidants of PCA and PAL in vitro.

\begin{tabular}{|c|c|c|c|c|}
\hline Disease model & PCA/PAL dosages & Model used & Oxidative stress mechanisms & References \\
\hline $\begin{array}{l}\text { Neurodegenerative } \\
\text { diseases }\end{array}$ & $\begin{array}{l}\text { PCA }(50,100,150 \\
\text { and } 200 \mu \mathrm{g} / \mathrm{ml})\end{array}$ & $\mathrm{H}_{2} \mathrm{O}_{2}$-treated $\mathrm{PC} 12$ cells & $\begin{array}{l}\text { Downregulation of lipid peroxidation and } \\
\text { upregulation of glutathione peroxidase and } \\
\text { superoxide dismutase activity }\end{array}$ & [118] \\
\hline $\mathrm{PD}$ & PAL $(20 \mu \mathrm{M})$ & $\mathrm{H}_{2} \mathrm{O}_{2}$-treated SH-SY5Y cells & $\begin{array}{l}\text { Activation of the Akt pathway and suppression } \\
\text { of excessive DJ-1 oxidation }\end{array}$ & {$[95]$} \\
\hline PD & PCA (1 mM) & 6-OHDA-treated PC12 cells & $\begin{array}{l}\text { Activation of } \mathrm{Nrf} 2 / \mathrm{HO}-1 \text { and suppression of } \\
\text { NF- } \kappa \mathrm{B} \text { signaling }\end{array}$ & {$[102]$} \\
\hline $\mathrm{PD}$ & PCA $(10 \mu \mathrm{M})$ & MPP-treated SH-SY5Y cells & $\begin{array}{l}\text { Mitigation of oxidative damage and } \\
\text { mitochondrial dysfunction through PLK2/p- } \\
\text { GSK } 3 \beta / \mathrm{Nrf} 2 \text { pathway }\end{array}$ & [101] \\
\hline $\mathrm{PD}$ & $\begin{array}{c}\text { PAL }(1,10 \text {, and } \\
100 \mu \mathrm{M} / 0.1,1 \text {, and } \\
10 \mu \mathrm{M})\end{array}$ & $\begin{array}{l}\mathrm{H}_{2} \mathrm{O}_{2} / 6-\mathrm{OHDA} \text {-treated } \\
\text { PC12 cells }\end{array}$ & $\begin{array}{l}\text { Induction of DJ-1 and reduction of } a- \\
\text { synuclein expression }\end{array}$ & {$[100]$} \\
\hline Diabetic cataract & $\begin{array}{l}\text { PAL }(20 \text { and } \\
50 \mu \mathrm{g} / \mathrm{ml})\end{array}$ & $\begin{array}{l}\text { High glucose- or S100b-treated } \\
\text { human lens epithelial cells }\end{array}$ & $\begin{array}{c}\text { Inhibition of TGF- } \beta 1 \text { expression and pSmad } 2 / \\
3 \text { nuclear accumulation }\end{array}$ & [135] \\
\hline Cerebral I/R injury & PAL $(80 \mu \mathrm{M})$ & Differentiated SH-SY5Y cells & $\begin{array}{c}\text { Induction of Nrf2 nuclear translocation and } \\
\text { HO-1 upregulation }\end{array}$ & {$[104]$} \\
\hline CVD & $\begin{array}{c}\text { PCA }(10,50, \text { and } \\
100 \mu \mathrm{M})\end{array}$ & $\begin{array}{l}\text { Palmitic acid- (PA-) treated } \\
\text { HUVECs. }\end{array}$ & $\begin{array}{l}\text { Suppression of Ac-CoA or Sirt1 and Sirt3 } \\
\text { activation through CD36/AMPK signaling }\end{array}$ & {$[146]$} \\
\hline CVD & PAL $(100 \mu \mathrm{M})$ & $\begin{array}{c}\text { Thoracic aortic smooth muscle } \\
\text { cells }\end{array}$ & $\begin{array}{l}\text { Inhibition of PDGF and other cytokines } \\
\text { cascade signaling }\end{array}$ & {$[15]$} \\
\hline CVD & PCA $(10-100 \mu \mathrm{M})$ & PA-treated HUVECs & $\begin{array}{c}\text { Induction of HO-1 and increasing SOD and } \\
\text { GPx-1 activity through LKB1-AMPK-Nrf2 } \\
\text { pathway }\end{array}$ & [145] \\
\hline Atherosclerosis & $\begin{array}{l}\text { PAL }(10,50, \text { or } \\
\quad 100 \mu \mathrm{M})\end{array}$ & HUVECS & $\begin{array}{l}\text { Reduction of ROS activity and inflammation, } \\
\text { increase of cAMP and GPER-1 }\end{array}$ & {$[143]$} \\
\hline Ischemic injury & $\begin{array}{l}\text { PCA }(10,20, \text { and } \\
40 \mu \mathrm{M})\end{array}$ & $\mathrm{H}_{2} \mathrm{O}_{2}$ treat $\mathrm{H} 9 \mathrm{C} 2$ cells & Reduction of ROS and elevation of GSH & {$[148]$} \\
\hline Liver injury & $\begin{array}{c}\text { PCA }(2.5,5 \text {, and } \\
10 \mu \mathrm{M})\end{array}$ & PA-treated AML-12 cells & $\begin{array}{c}\text { Activation of SIRT3 and suppression of } \\
\text { ACSF3-mediated fatty acid metabolism } \\
\text { disorder }\end{array}$ & {$[150]$} \\
\hline Liver injury & PCA $(10 \mu \mathrm{M})$ & $\begin{array}{l}\text { Primary hepatocytes, AML- } \\
12 \text { cells }\end{array}$ & $\begin{array}{l}\text { Upregulation of miR-219a-5p expression and } \\
\text { suppression of } \mathrm{p} 66 \mathrm{shc} \text {-mediated ROS } \\
\text { formation }\end{array}$ & [149] \\
\hline Liver injury & $\begin{array}{l}\text { PCA } 20 \mathrm{ug} / \mathrm{ml}, \text { PAL } \\
20 \mathrm{ug} / \mathrm{ml}\end{array}$ & $\begin{array}{l}\text { Ccl4 treatment isolated rat } \\
\text { hepatocytes }\end{array}$ & $\begin{array}{l}\text { Inhibit MDA production in liver microsomes } \\
\text { and peroxidative damage to the surfaces of rat } \\
\text { hepatocytes. }\end{array}$ & {$[156]$} \\
\hline Cancer & PCA (500 ppm) & $\begin{array}{l}\text { N-nitroso-methyl } \\
\text { benzylamine- (NMBA-) } \\
\text { induced esophageal } \\
\text { tumorigenesis }\end{array}$ & $\begin{array}{l}\text { Inhibition of tumorigenesis and inflammatory } \\
\text { signaling }\end{array}$ & {$[160]$} \\
\hline Cancer & PCA $(100 \mu \mathrm{M})$ & $\begin{array}{l}\text { HepG2 hepatocellular } \\
\text { carcinoma cells }\end{array}$ & $\begin{array}{l}\text { Induction of JNK-dependent hepatocellular } \\
\text { carcinoma cell death }\end{array}$ & {$[159]$} \\
\hline Cancer & $\begin{array}{c}\text { PAL }(0.25,0.5, \text { and } \\
1 \mu \mathrm{M})\end{array}$ & Cisplatin-treated HK2 cells & $\begin{array}{l}\text { Suppression of cisplatin-induced death } \\
\text { through inhibition of Nox } 4\end{array}$ & {$[164]$} \\
\hline Pulmonary injury & PCA $(25 \mu \mathrm{M})$ & Fluoride-treated A549 cells & $\begin{array}{l}\text { Inhibition of fluoride toxicity through } \\
\text { regulation of intracellular calcium level, } \\
\text { bioavailability, redox signaling, and } \\
\text { mitochondrial membrane integrity }\end{array}$ & [174] \\
\hline
\end{tabular}

3.1.3. Other Central Nervous System Diseases. PCA has demonstrated antidepressant potential in stressed animals. It improved endogenous antioxidant enzymatic and antidepressant activities through the upregulation of brain monoamines [118, 120]. PCA (100 and $200 \mathrm{mg} / \mathrm{kg}$ body weight) inhibited oxidative activity through suppression of MDA production, induction of enzymatic antioxidant activity, and attenuation of pro-inflammatory cytokines IL-6 and TNF- $\alpha$ in the cerebral cortex and hippocampus in acute restraint stress (ARS) mouse model and olfactory bulbectomized (OBX) mouse model of depression $[5,121$, 122]. PCA promoted antioxidant activities, suppressed lipid peroxidation, and decreased the serum corticosterone level in Swiss albino mice with ARS.

PCA alleviated cadmium (Cd)-induced cortical toxicity in male rats through activation of the antioxidant defense system and suppression of the inflammation and apoptosis mediated by the Nrf2/ARE pathway [108]. PCA pre-administration suppressed the cadmium chloride $\left(\mathrm{CdCl}_{2}\right)$ induced apoptotic events through inhibition of 
TABLe 3: Summary of the effects on antioxidants of PCA and PAL in vivo.

\begin{tabular}{|c|c|c|c|c|}
\hline Diseases & PCA/PAL dosages & Model used & Oxidative stress mechanisms & References \\
\hline $\begin{array}{l}\text { Neurodegenerative } \\
\text { diseases }\end{array}$ & $\begin{array}{l}\text { PCA }(5 \mathrm{mg} / \mathrm{kg} / \mathrm{day} \text {, } \\
\text { i.p. })\end{array}$ & Male SD rats & $\begin{array}{l}\text { Downregulation of lipid peroxidation and } \\
\text { upregulation of glutathione peroxidase and } \\
\text { superoxide dismutase activity }\end{array}$ & [118] \\
\hline $\mathrm{PD}$ & $\begin{array}{l}\text { PAL mice }(7.5,15 \text {, and } \\
30 \mathrm{mg} / \mathrm{kg} / 12 \mathrm{~h} \text { p.o. }) \text { and } \\
\text { rats }(20 \text { and } 40 \mathrm{mg} / \mathrm{kg} / \\
12 \mathrm{~h} \text {, p.o. })\end{array}$ & $\begin{array}{l}\text { MPTP-induced PD in mice } \\
\text { and 6-OHDA-induced SD } \\
\text { rats }\end{array}$ & $\begin{array}{l}\text { Induction of DJ-1 and reduction of } a \text {-synuclein } \\
\text { expression }\end{array}$ & {$[100]$} \\
\hline $\mathrm{PD}$ & $\begin{array}{l}\text { PCA }(10 \text { and } 20 \mathrm{mg} / \mathrm{kg} / \\
\text { day, i.p. })\end{array}$ & MPTP-intoxicated mice & $\begin{array}{l}\text { Mitigation of oxidative damage and } \\
\text { mitochondrial dysfunction through PLK2/p- } \\
\text { GSK3 } \beta / \text { Nrf2 pathway }\end{array}$ & [101] \\
\hline $\mathrm{PD}$ & $\operatorname{PCA}(6,12$, and $25 \mu \mathrm{M})$ & $\begin{array}{l}\text { 6-OHDA-induced PD } \\
\text { zebrafish }\end{array}$ & $\begin{array}{l}\text { Downregulation of lipid peroxidation and } \\
\text { induction of antioxidant enzymes (SOD, CAT, } \\
\text { and GSH) activity }\end{array}$ & {$[102]$} \\
\hline Cerebral ischemic & $\begin{array}{l}\text { PCA }(200 \mathrm{mg} / \mathrm{kg} / \mathrm{day} \text {, } \\
\text { i.p. })\end{array}$ & Cerebral ischemic rats & $\begin{array}{l}\text { Suppression of MDA formation and induction } \\
\text { of endogenous antioxidant (SOD, CAT, and } \\
\text { GSH) activity }\end{array}$ & [117] \\
\hline Depression & $\begin{array}{l}\text { PCA (100 and } 200 \mathrm{mg} / \\
\text { kg/day, p.o.) }\end{array}$ & $\begin{array}{l}\text { OBX induced depressive- } \\
\text { like behavior in Wistar rat } \\
\text { model }\end{array}$ & $\begin{array}{l}\text { Induction of BDNF, 5-HT, DA, and NE and } \\
\text { suppression of MDA, IL-6, and TNF- } \alpha\end{array}$ & {$[121]$} \\
\hline Depression & $\begin{array}{l}\text { PCA (100 and } 200 \mathrm{mg} / \\
\mathrm{kg} / \text { day, p.o. })\end{array}$ & $\begin{array}{l}\text { ARS-induced depressive- } \\
\text { like behavior in Swiss } \\
\text { albino mice }\end{array}$ & Induction of antioxidant marker levels/activities & [106] \\
\hline I/R injury & $\begin{array}{l}\text { PAL }(40 \mathrm{mg} / \mathrm{kg} / \mathrm{day} \text {, } \\
\text { i.v. })\end{array}$ & $\begin{array}{c}\text { Middle cerebral artery } \\
\text { occlusion- (MCAO-) } \\
\text { induced I/R injury in SD } \\
\text { rats }\end{array}$ & Activation of $\mathrm{PKC} \varepsilon / \mathrm{Nrf} 2 / \mathrm{HO}-1$ pathway & {$[104]$} \\
\hline Diabetes & $\begin{array}{l}\text { PCA (50, 100, and } \\
200 \mathrm{mg} / \mathrm{kg} / \text { day, p.o.) }\end{array}$ & STZ-diabetic rats & Induction of antihyperglycemic effect & [128] \\
\hline Diabetes & $\begin{array}{l}\text { PCA (50 and } 100 \mathrm{mg} / \\
\text { kg/day, p.o.) }\end{array}$ & T1DM adult male SD rats & $\begin{array}{l}\text { Inhibition of brain oxidative stress by } \\
\text { improving brain mitochondrial function in } \\
\text { T1DM rats }\end{array}$ & [91] \\
\hline Diabetes & $\begin{array}{l}\text { PCA (50 and } 100 \mathrm{mg} / \\
\text { kg/day, p.o.) }\end{array}$ & DC-treated Wistar rats & $\begin{array}{l}\text { Induction of antioxidant, hypoglycemic, } \\
\text { insulin-sensitizing, and anti-inflammatory } \\
\text { effects }\end{array}$ & [7] \\
\hline Diabetes & $\begin{array}{l}\text { PCA }(50 \mathrm{mg} / \mathrm{kg} / \mathrm{day}, \\
\text { p.o. })\end{array}$ & STZ-diabetic rats & $\begin{array}{l}\text { Induction of endogenous antioxidant, } \\
\text { suppression of lipid peroxidation, } \\
\text { inflammation, caspase-3, and } \\
\text { acetylcholinesterase activities }\end{array}$ & {$[107]$} \\
\hline CVD & $\begin{array}{l}\text { PCA }(50,100 \text {, and } \\
200 \mathrm{mg} / \mathrm{kg} / \text { day, p.o.) }\end{array}$ & $\begin{array}{l}\text { Glucocorticoid-induced } \\
\text { hypertension in rats }\end{array}$ & $\begin{array}{c}\text { Suppression of plasma } \mathrm{H}_{2} \mathrm{O}_{2} \text { concentration and } \\
\text { induction of FRAP values }\end{array}$ & {$[140]$} \\
\hline CVD & $\begin{array}{l}\text { PCA (200 mg/kg/day, } \\
\text { p.o.) }\end{array}$ & $\begin{array}{l}\text { Male aging spontaneously } \\
\text { hypertensive rats }\end{array}$ & $\begin{array}{l}\text { Induction of insulin and IGF-1 in aging } \\
\text { hypertension by PI3K-NOS-NO signaling }\end{array}$ & [139] \\
\hline CVD & $\begin{array}{l}\text { PCA }(100 \mathrm{mg} / \mathrm{kg} / \mathrm{day} \\
\text { p.o. })\end{array}$ & $\begin{array}{l}\text { TCDD-induced } \\
\text { cardiotoxicity in male SD } \\
\text { rats }\end{array}$ & Suppression of oxidative stress & [136] \\
\hline CVD & $\begin{array}{l}\text { PCA (50 and } 100 \mathrm{mg} / \\
\text { kg/day, p.o.) }\end{array}$ & $\begin{array}{l}\text { Dex-induced hypertensive } \\
\text { male Wistar rats }\end{array}$ & $\begin{array}{c}\text { Induction of eNOS and suppression of NOX4 } \\
\text { expression }\end{array}$ & [132] \\
\hline CVD & $\begin{array}{l}\text { PCA (100 mg/kg/day, } \\
\text { p.o.) }\end{array}$ & $\begin{array}{l}\text { HFD-fed male C57BL/6J } \\
\text { mice }\end{array}$ & $\begin{array}{l}\text { Suppression of Ac-CoA or Sirt1 and Sirt3 } \\
\text { activation through CD36/AMPK signaling }\end{array}$ & [146] \\
\hline CVD & $\begin{array}{l}\text { PAL }(10,30, \text { and } \\
100 \mathrm{mg} / \mathrm{kg} / \text { day, i.g. })\end{array}$ & $\begin{array}{l}\text { Isoproterenol-induced } \\
\text { cardiac hypertrophy in SD } \\
\text { rats }\end{array}$ & Inhibition of JAK2/STAT3 signaling & {$[141]$} \\
\hline CVD & $\begin{array}{l}\text { PAL (100 mg/kg/day, } \\
\text { p.o.) }\end{array}$ & $\begin{array}{l}\text { Common Carotid Balloon } \\
\text { injury SD rats }\end{array}$ & $\begin{array}{l}\text { Reduction of ROS activity and inflammation, } \\
\text { increase of cAMP and GPER-1, increased CD31 } \\
\text { and GPER-1, and decreased VCAM-1 and } \\
\text { CD40 expression }\end{array}$ & [143] \\
\hline Myocardial fibrosis & $\begin{array}{l}\text { PAL }(30 \mathrm{mg} / \mathrm{kg} / \mathrm{day} \\
\text { i.p.), PCA }(30 \mathrm{mg} / \mathrm{kg} / \\
\text { day, i.p.) }\end{array}$ & $\begin{array}{l}\text { Isoprenaline- (ISO-) } \\
\text { treated C57BL/6 mice }\end{array}$ & $\begin{array}{c}\text { Modulation of collagen conformational } \\
\text { dynamics }\end{array}$ & {$[142]$} \\
\hline Ischemic injury & PCA $(4 \mathrm{mg} / \mathrm{kg}$, i.p. $)$ & $\mathrm{I} / \mathrm{R}$ injury $\mathrm{SD}$ rats & Elevation of GSH levels and reduction of ROS & {$[148]$} \\
\hline
\end{tabular}


TABle 3: Continued.

\begin{tabular}{|c|c|c|c|c|}
\hline Diseases & PCA/PAL dosages & Model used & Oxidative stress mechanisms & References \\
\hline Obesity & PCA $(100 \mu \mathrm{M})$ & $\begin{array}{l}\text { Visceral adipose tissue } \\
\text { from female obese } \\
\text { individuals }\end{array}$ & Suppression of PTP1B activity & {$[8]$} \\
\hline NAFLD & $\begin{array}{l}\text { PCA, rats }(10 \text { and } \\
20 \mathrm{mg} / \mathrm{kg} / \text { day }), \text { mice } \\
(30 \mathrm{mg} / \mathrm{kg} / \text { day })\end{array}$ & $\begin{array}{l}\text { HFD-fed male SD rats, } \\
\text { C57BL/6 mice, and } \\
\text { SIRT3-/- mice }\end{array}$ & $\begin{array}{l}\text { Suppression of NAFLD through the SIRT3/ } \\
\text { ACSF3 signaling }\end{array}$ & [150] \\
\hline Liver injury & $\begin{array}{l}\text { PCA }(0.45,0.9 \text {, and } \\
1.8 \mathrm{mg} / \mathrm{kg} / \text { day, i.p. })\end{array}$ & $\begin{array}{l}\text { Cisplatin-induced acute } \\
\text { kidney injury in mice }\end{array}$ & $\begin{array}{c}\text { Suppression of cisplatin-induced death through } \\
\text { inhibition of Nox } 4\end{array}$ & [164] \\
\hline Liver injury & $\begin{array}{l}\text { PCA (50 and } 100 \mathrm{mg} / \\
\text { kg/day, p.o.) }\end{array}$ & t-BHP-treated male SD rats & $\begin{array}{l}\text { Induction of antioxidant enzymatic activities } \\
\text { and suppression of stress signal transduction }\end{array}$ & {$[88]$} \\
\hline Liver injury & $\begin{array}{l}\text { PCA (10 and } 20 \mathrm{mg} / \mathrm{kg} / \\
\text { day, p.o.) }\end{array}$ & ALD male SD rat model & $\begin{array}{c}\text { Induction of miR-219a-5p expression and } \\
\text { suppression of p66shc-mediated ROS } \\
\text { formation }\end{array}$ & [149] \\
\hline Liver injury & $\begin{array}{l}\text { PCA }(100 \mathrm{mg} / \mathrm{kg} / \mathrm{day}, \\
\text { p.o. })\end{array}$ & $\begin{array}{l}\text { D-GalN-induced } \\
\text { hepatotoxicity in male } \\
\text { albino Wistar rats } \\
\text { Cadmium-induced }\end{array}$ & $\begin{array}{c}\text { Induction of antihyperlipidemic activity and } \\
\text { DNA damage protection }\end{array}$ & {$[152]$} \\
\hline $\begin{array}{l}\text { Liver and kidney } \\
\text { injury }\end{array}$ & $\begin{array}{l}\text { PCA (10 and } 20 \mathrm{mg} / \mathrm{kg} / \\
\text { day, p.o.) }\end{array}$ & $\begin{array}{l}\text { hepatotoxicity and } \\
\text { nephrotoxicity in male } \\
\text { Wistar rats }\end{array}$ & $\begin{array}{l}\text { Suppression of lipid peroxidation and elevation } \\
\text { of kidney parameters and liver marker enzymes }\end{array}$ & [153] \\
\hline Kidney injury & $\begin{array}{l}\text { PCA }(10 \text { and } 20 \mathrm{mg} / \mathrm{kg} / \\
\text { day, i.p.) }\end{array}$ & DOX-treated Wistar rats & $\begin{array}{l}\text { Reversion of kidney antioxidant enzymes CAT, } \\
\text { SOD, GPx, GSH, and GST levels }\end{array}$ & [166] \\
\hline Aging & PCA $(100$ and $200 \mu \mathrm{M})$ & $\begin{array}{l}\text { Age-synchronized N2 } \\
\text { Caenorhabditis elegans }\end{array}$ & $\begin{array}{l}\text { Inhibition of intracellular ROS level and } \\
\text { antioxidant enzyme activities of nematodes }\end{array}$ & {$[120]$} \\
\hline $\begin{array}{l}\text { Reproductive } \\
\text { damage }\end{array}$ & $\begin{array}{l}\text { PCA (10 and } 40 \mathrm{mg} / \mathrm{kg} / \\
\text { day, p.o.) }\end{array}$ & $\begin{array}{l}\text { Testosterone propionate- } \\
\text { (TP-) induced BPH } \\
\text { castrated albino Wistar rat }\end{array}$ & Reduction of MPO activity, MDA, and NO level & [168] \\
\hline Sepsis & $\begin{array}{l}\text { PAL }(25,50, \text { and } \\
100 \mathrm{mg} / \mathrm{kg} \text {, injection } \\
\text { into the tail vein) }\end{array}$ & $\begin{array}{l}\text { CLP-induced sepsis in } \\
\text { male Sprague-Dawley rats }\end{array}$ & Suppression of HMGB1 and NF- $\kappa \mathrm{B}$ signaling & [14] \\
\hline
\end{tabular}

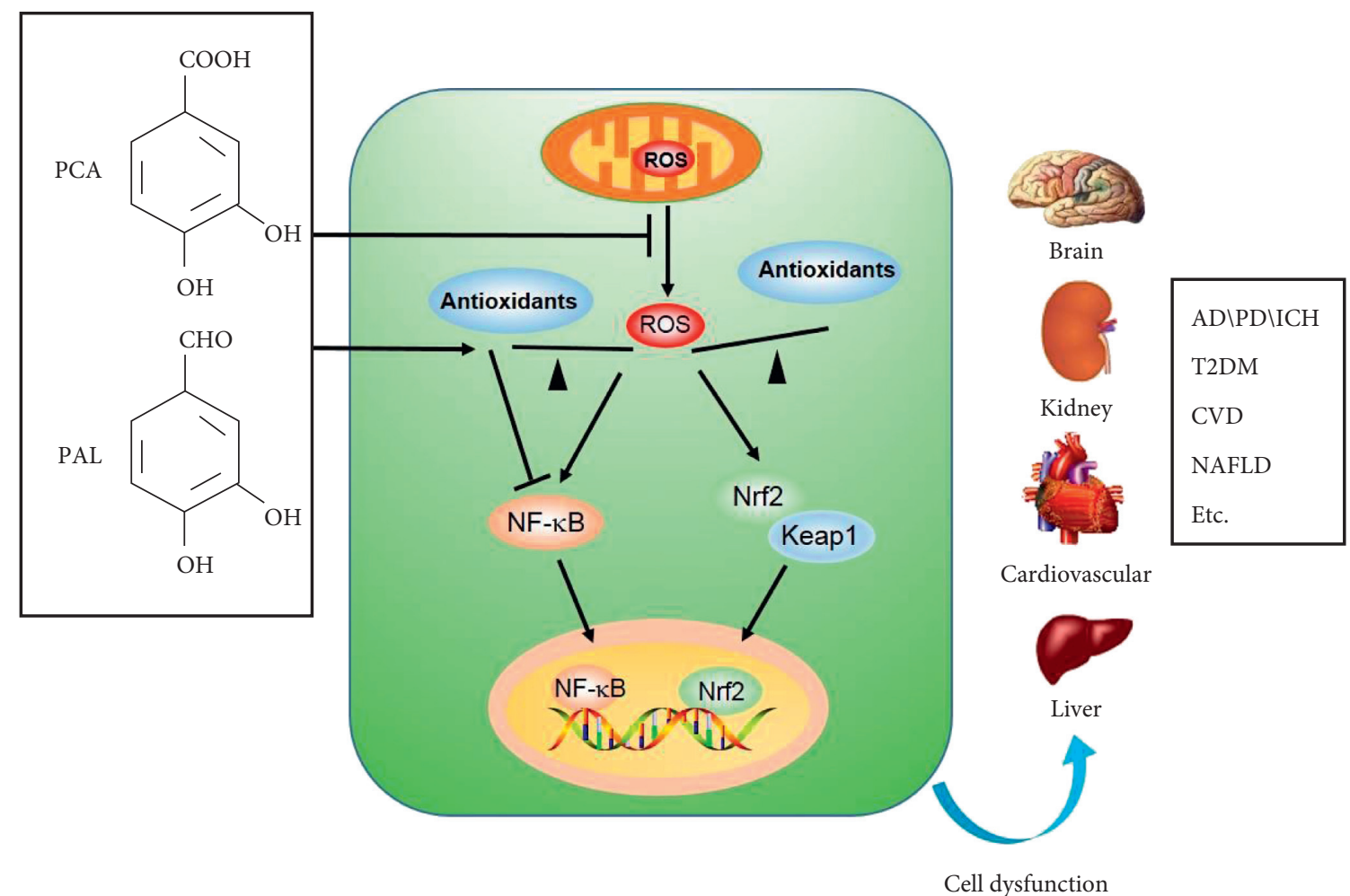

Figure 3: Antioxidant mechanisms of PCA and PAL. 
mitochondria-caspase signaling pathway and mitigated Cdinduced neurotoxicity by activating $\mathrm{Na}+\mathrm{K}+$-ATPase, butyrylcholinesterase, acetylcholinesterase, and antioxidant enzymes [124].

Diabetes-induced neurobehavioral and biochemical dysfunction was also alleviated by PCA administration by improving the endogenous antioxidant status; inhibition of lipid peroxidation; and downregulation of acetylcholinesterase, inflammation, and caspase- 3 activities [107]. PCA treatment attenuated brain oxidative stress through inhibition of brain mitochondrial dysfunction and hyperglycemia in rats with streptozotocin (STZ)-induced diabetes [4].

3.2. Antioxidant Properties in Diabetes. Diabetic cardiomyopathy (DC) is a significant complication in type 2 diabetes mellitus (T2DM). ROS production and oxidative stress in diabetic hearts are being increasingly reported. Excessive oxidative stress correlated with lipid overload, indicating that fatty acid played a role in ROS generation [125]. PCA treatment prevented oxidative damage from lipids and proteins-induced elevation in ROS levels observed in the myocardial tissues of T2D rats. PCA upregulated endogenous antioxidants and recovered the myocardial physiology in these rats through $\mathrm{PARP} / \mathrm{PKC} / \mathrm{NF}-\kappa \mathrm{B}$ signaling pathway-mediated anti-inflammatory, antioxidant, insulin-sensitizing, and hypoglycemic effects, which also stimulated glucose metabolism and modulated lipid and glycemic status in the skeletal muscles through IRS1/PI3K/ AKT/AMPK/GLUT4/P38 signaling pathways [7]. The diabetes-induced cardiac dysfunction caused by oxidative stress in rats with STZ-induced diabetes was reversed by oral PCA treatment (50 or $100 \mathrm{mg} / \mathrm{kg} /$ day) through its antioxidant and antihyperglycemic activities [126, 127]. Several doses of PCA decreased blood glucose and hemoglobin A1c (HbA1c) due to its antihyperglycemic effects [127-129].

In human omental adipocytes, PCA treatment also reversed oxidized low-density lipoprotein (ox-LDL)-induced impairment of glucose uptake through the induction of an insulin-like effect and upregulation of the entire insulin signaling pathway $[8,130,131]$. Oral pretreatment with PCA might counteract insulin resistance status partly through induction of AKT phosphorylation and mitigation of phosphoenolpyruvate carboxykinase (PEPCK) and glucose6-phosphatase (G6Pase) expression in dexamethasone (Dex)-induced hyperinsulinemia and insulin resistance in rats [132].

PAL was also found to be a potent aldose reductase (AR) inhibitor and might be useful for preventing and/or treating diabetic complications $[48,79]$. It showed a significant inhibitory effect on methylglyoxal-mediated protein glycation and protected against protein damage caused by hyperglycemia [133]. As the primary ingredient of Danshen injection (DSI), PAL enhanced the apical-to-basolateral (AP-BL) transport of gliquidone in Caco-2 cell monolayers and increased the absorption of gliquidone [134]. PAL $(25 \mathrm{mg} / \mathrm{kg}$ body weight) significantly reduced blood glucose levels and inhibited lens opacity in diabetic cataract induced by STZ in rats. The protective mechanism was through inhibition of transforming growth factor (TGF)- $\beta 1$ expression and PSmad2/3 nuclear accumulation caused by high glucose level or S100B protein in human lens epithelial cells [135].

\subsection{Antioxidant Properties in Cardiovascular Diseases.}

PCA has the potential to be a therapeutic candidate for hypertrophic cardiomyopathy as it decreased the 2,3,7,8tetrachlorodibenzo-p-dioxin (TCDD)-induced cardiotoxicity by suppressing the thiobarbituric acid reactive- substances (TBARS) level and upregulating the GSH-PX, GSH, SOD, and CAT levels in the rat heart tissue [136]. It suppressed cleaved caspase- 3 expression and reduced hypoxia/ reoxygenation-induced cardiomyocyte apoptosis rate [136]. Treatment with PCA and glibenclamide counteracted oxidative damage by suppressing total cholesterol (TC), lowdensity lipoprotein cholesterol (LDL-C), very low-density lipoprotein cholesterol (VLDL-C), triglyceride (TG), and lipid peroxidation markers and reduced diabetes-induced cardiac dysfunction $[127,138]$. PCA administra-tion for 12 weeks augmented insulin and IGF-1-induced endotheliumdependent vasorelaxation in spontaneously hypertensive male rats by activating the PI3K-NOS-NO pathway [139]. PCA showed hypoglycemic, insulin-sensitizing, hypolipidemic, and antioxidant effects in glucocorticoid (GC)-induced hypertensive rats [140]. It prevented hypertension and weight loss, reduced plasma $\mathrm{H}_{2} \mathrm{O}_{2}$ concentration, and increased ferric reducing antioxidant power (FRAP) values in a dose-dependent manner [140]. Furthermore, PCA showed antihypertensive and antioxidant effects against Dex-induced hypertension by improving the antioxidant capacity and reducing the blood pressure [132]. It also mitigated vascular dysfunction induced by Dex and enhanced the relaxation in aortic rings induced by acetylcholine ( $\mathrm{ACh}$ ), through induction of endothelial nitric oxide syn-thase (eNOS) and reduction of NADPH oxidase (NOX4) expression [132]. PAL was also shown to provide relief from atherosclerosis by inhibiting lipopolysaccharide (LPS)-induced endothelial apoptosis. It inhibited the JAK2/STAT3 signaling pathway and protected against cardiac hypertrophy induced by isoproterenol (ISO) and effectively suppressed myocardial fibrosis in ISO-induced heart failure mouse model [141]. It provided cardioprotection against myocardial ischemia/reperfusion injury in rats by suppressing NF- $\mathrm{kB}$-mediated inflammatory response [11]. Moreover, researchers observed that PAL bound to collagen I protein through lysine residues via covalent crosslinking, making it a crucial pharmacological target for treating myocardial fibrosis [142]. It showed inhibitory effects against angiogenesis by increasing CD31 and GPER-1 and decreasing VCAM-1 and CD40 expression aortic ring assay in rats [143]. PAL protected SH-SY5Y cells from $\mathrm{H}_{2} \mathrm{O}_{2}$-induced oxidative stress through stimulation of antioxidants (SOD2 and CAT) and B-cell lymphoma 2 (Bcl-2), as well as forkhead box O (FoxO) 3a and sirtuin-1 (SIRT1) [144].

A study noted that PCA could induce HO-1 expression and increase SOD and GSH-PX 1 (GPx-1) activities through the LKB1-AMPK-Nrf2 pathway in human umbilical vein 
endothelial cells (HUVECs) in vitro [145]. The same group also found that PCA deacetylation played a role in manganese-dependent SOD (MnSOD), as well as Ac-CoA generation or SIRT1 and SIRT3 activation through the CD36/AMPK signaling pathway [146]. Research has shown that due to its location in the mitochondria, MnSOD plays a significant role as a ROS scavenger, whereas SIRT1 and SIRT3 are vital for the control of metabolic processes. PCA prevented apoptosis induced by oxLDL by activating JNK/ Nrf2 survival signals in J774A.1 macrophages, an in vitro model for investigating pathological atherosclerosis processes [147]. PAL is capable of inhibiting vascular smooth muscle cells' (VSMCs) proliferation and migration due to its ROS scavenging ability through attenuation of platelet-derived growth factor (PDGF) and other cytokines' signaling cascades [15]. It protects endothelial cells from inflammation by attenuating $G$ protein-coupled estrogen receptor-1 (GPER-1)-mediated endothelial dysfunction [143, 148].

3.4. Antioxidant Properties in Liver Injury. PCA prevented ROS formation in alcoholic liver disease (ALD) by stimulating the expression of miR-219a-5p (a tumor suppressor) and repressing p66Shc (an adaptor protein involved in ROS formation in mitochondria) [149]. PCA treatment in nonalcoholic fatty liver disease (NAFLD) activated SIRT3 partly by suppressing fatty acid metabolism, mediated by ACSF3 [150]. It was effective in the treatment of I/R-induced liver injury through inhibition of p66Shc in mice and also in restoring D-galactosamine- or cadmium-induced fatty liver in rats [151-153]. PCA inhibited Dex-induced liver steatosis by reducing serum aspartate aminotransferase (AST) and alanine aminotransferase (ALT) activity. PCA counteracted hepatotoxicity induced by t-BHP by blocking MDA and ROS generation or stress-induced changes in enzyme activity [88].

PCA demonstrated antioxidative and antiapoptotic effects on I/R-induced liver injury in Caco-2 cell line by suppressing p66Shc [151]. It also inhibited hepatitis B virus replication in HepG2 2.2.15 cell line [154] and also hampered the catalytic activity of cytochrome P450 enzyme by downregulating CY3A4 in human liver microsomes [155]. PCA and PAL counteracted $\mathrm{H}_{2} \mathrm{O}_{2}$-induced hemolysis of rat erythrocytes through inhibition of MDA production in liver microsomes and peroxidative damage to the hepatocytes' surfaces [156].

3.5. Antioxidant Properties in Cancer. As a significant anthocyanin metabolite in dietary polyphenol-rich food, the antioxidative effects of PCA were evident during cancer progression in humans [157]. It could induce cell death through suppression of Bcl-2 expression and retinoblastoma (RB) phosphorylation in human leukemia cells and c-Jun Nterminal kinase-dependent signal transduction in HepG2 hepatocellular carcinoma cells [158, 159]. The anthocyanin and PCA present in black raspberries suppressed esophageal tumorigenesis induced by $\mathrm{N}$-nitroso-methyl benzylamine (NMBA), through inhibition of COX-2, iNOS, p-NF-kB, and sEH biomarkers and PTX3 cytokine expression [160].
Similarly, PAL also showed anti-tumor activity by hindering the proliferation of MCF-7 human breast cancer cells through activation of $\mathrm{DPPH}$ radical-scavenging activity [161].

An effective cancer therapy strategy involves manipulation of the ROS levels. Pre-treatment with PCA inhibited DBP-diol-induced DNA adduct formation and mutagenesis through enzyme inhibition or phase 2 enzyme induction [162]. PCA inhibits ovarian cancer cells proliferation through p53-independent apoptosis and autophagy induction along with ROS reduction [163]. PAL suppressed cisplatin-induced acute kidney injury (AKI) by inhibiting NOX-mediated renal inflammation and oxidative stress, making PAL and its derivatives potential chemoprotective agents [164]. It also suppressed breast cancer cell growth and promoted apoptosis of these cells by downregulating bcatenin- and cyclin D1-mediated multiple signal pathways [34].

3.6. Antioxidant Properties in Other Diseases. PCA counteracted TCDD-induced reproductive damage in male rats. The use of PCA in combination with TCDD minimized the latter's toxicity through suppression of histopathological changes and TBARS levels and increasing SOD, CAT, GPX antioxidant enzymes activity; GSH levels; and sperm concentration and motility [165]. PCA also showed a protective effect against nephrotoxicity resulting from doxorubicin (DOX)-induced damage to the renal cells [166]. Pretreatment with PCA prior to the administration of DOX reduced the MDA levels, modulated iNOS and cyclooxygenase-2 (COX2) activities, and improved renal function, as well as enhanced the antioxidant parameters including GSH level and activities of the antioxidant enzymes SOD, CAT, GSHPX and glutathione s-transferase (GST) in the kidney [166].

PCA protected renal I/R injury by suppressing oxidative stress and tissue damage [167]. It significantly controlled the serum levels of MDA and TNF- $\alpha$, and renal MDA level; while on the other hand, it upregulated the serum and renal total antioxidant status (TAS) and SOD levels, and histopathological scores [167]. PCA administration for 28 days suppressed benign prostatic hyperplasia induced by testosterone through reduction of myeloperoxidase (MPO) activity, and NO and MDA levels. Furthermore, it restored the histological architecture of the prostate epithelium in rats with benign prostatic hyperplasia (BPH) [168].

The acute lung injury (ALI) induced by lipopolysaccharide (LPS) in mice was repaired by PCA by downregulating $\mathrm{p} 38 / \mathrm{MAPK}$ and $\mathrm{NF}-\mathrm{\kappa B}$ signal pathways [169]. It controlled dermal wounds in Wistar albino rats by elevating the levels of SOD, CAT, and GPx antioxidant enzymes and suppressing the inflammatory markers [170]. PAL inhibited TGF- $\beta 1$-stimulated epithelial-mesenchymal transition (EMT) in A549 cells and controlled bleomycin (BLM)-induced pulmonary fibrosis in rats through HMGB1/RAGE pathway regulation [9].

Pretreatment with PCA-enhanced ROS generation, lipid peroxidation, and DNA fragmentation; upregulated SOD, $\mathrm{CAT}, \mathrm{NAD}+\mathrm{NADH}$ levels; and downregulated GSH and 
MDA levels-consequently leading to bacterial cell death in E. coli, P. aeruginosa, and S. aureus probably through Fenton chemistry, autoxidation, and electron transport chain inhibition [171]. Dose-dependent PCA administration reduced multinucleated osteoclasts formation and tartrateresistant acid phosphatase (TRAP) activity in RANKLtreated RAW264.7 murine macrophage cells through a decrease in the ROS and lipid peroxide levels and enhancement of the antioxidant status [172]. PCA suppressed the expression of osteoclast-specific markers such as $\mathrm{Ca}$ thepsin, MMP, c-Src, TRAP, TRAF-6, and transcription factors AP-1 and NFATc1; MAPK activation; as well as NF$\mathrm{kB}$ and COX-2 inflammatory marker levels [172]. PAL could also reduce LPS-induced NO production, stimulate free radical scavenging activity in RAW264.7 macrophages [12], block NF- $\kappa \mathrm{B}$ activation, and decrease HMGB1 expression during cecal ligation and puncture (CLP)-induced sepsis [14]. In osteoarthritis (OA) induced by anterior cruciate ligament transection (ACLT), PCA suppressed osteoclastogenesis by modulating the MAPK, ATK, and NF- $\kappa B$ signaling pathways [173]. It also altered the aging rate and life span of the nematode, Caenorhabditis elegans. It alleviated intracellular ROS level and CAT and SOD antioxidant enzyme activities [120].

\section{Clinical Studies of PCA and PAL in TCM}

PCA and PAL are the active ingredients in many traditional Chinese medicines, such as Salviae miltiorrhiza (Danshen) and Acanthopanax senticosus (Ciwujia). They were also detected in some proprietary traditional Chinese herbal injections, such as Danshen injection (DSI), Compound Danshen injection (CDSI), Xiangdan injection (XDI), Guanxinning injection (GXN), Danhong injection (DHI), and XueBiJing injection (XBJ). These have been widely used in the treatment of cardiovascular (such as acute coronary syndrome and angina pectoris) and cerebrovascular diseases (such as stroke) in China for many years. Their pharmacological properties related to PCA and PAL include antioxidant, anticoagulatory, hypolipidemic, antiapoptotic, antiinflammatory, vasodilatory, and angiogenesis-promoting actions [175].

DSI is made from only Salviae miltiorrhiza, whereas CDSI and XDI are made up of Danshen and Dalbergia odorifera (Jiangxiang). DHI consists of two famous Chinese herbal medicines, Danshen and Carthami flos (Honghua) [176]; GXN is prepared from Danshen and Rhizoma Chuanxiong (Chuan xiong). According to related studies, the main effective constituent of these injections is Danshen, which contains high levels of PCA and PAL [175, 177-180]. Similarly, in XBJ, a total of 17 Danshen catechols were detected, among which the amount of PCA and PAL was high [181]. Acanthopanax senticosus extract injection (ASI) also contains many ingredients including PCA [182]. PAL can be largely oxidized to PCA in vivo, which is an abundant circulating metabolite despite its low content in the injection. Although some injections are composed of several medicines besides Danshen, they do not affect the main components of Danshen. A comparative pharmacokinetic study suggested that the presence of Honghua constituents along with Danshen in DHI might have negligible influences on the pharmacokinetics of the polyphenols derived from Danshen [175].

4.1. Antioxidant Effect on Central Nervous System Disease. DHI protects patients from cerebral injury during coronary artery bypass graft (CABG) surgery with cardiopulmonary bypass $(\mathrm{CPB})$ through antioxidation, antiinflammation, and immune factors regulation mechanisms [183, 183]. Composite salvia injection (CSI) has the potential to reduce the oxygen-free radical damage and regulate the apolipoprotein metabolism in patients with ischemic cerebral infarction by decreasing the serum levels of lipid peroxide (LPO) and apolipoprotein B100 (APOB100) and increasing the SOD and ApoA1 levels [185]. It has also been noted to effectively reduce the serum levels of MPO and hypersensitive C-reactive protein (hs-CRP) in patients with severe preeclampsia (PE) [186].

\subsection{Antioxidant Effect on Type 2 Diabetes Mellitus (T2DM)} Diseases. CWJI has a protective effect in type 2 diabetes (T2DM) patients with persistent microalbuminuria and normal blood pressure by inhibiting kidney endothelin (ET) synthesis, reducing the level of urinary albumin excretion (UAE), plasma ET concentration, and urinary ET excretion [187]. CSI in combination with western medicine (WM) was found to be effective in the treatment of diabetic foot by accelerating the median motor nerve and sensory nerve conduction speed and lowering the blood viscosity [188].

4.3. Antioxidant Effect on Cardiovascular Diseases. GXN is widely used to treat angina, hyperlipidemia, and coronary heart disease $[189,190]$. When patients with chronic stable angina were treated with DHI, they showed a clinically significant change, defined as at least a 20-point improvement in the angina frequency score on the Seattle Angina Questionnaire. The other secondary efficacy and safety outcomes were also assessed at the same time [191]. DSI decreased the endothelin-1 (ET-1) response and increased postoperative hemodynamic stability; reduced myocardial damage; and corrected the imbalance in the levels of vasoactive mediators after surgery in children with congenital heart defects [192]. It improved the plasma (ET-1), nitric oxide (NO), and apolipoprotein levels and effectively relieved the clinical symptoms of patients with arteriosclerosis obliterans (ASO) [120]. Shenmai-Danshen (SM-DS) injection im-proved MDA, SOD, interleukin 6 (IL-6), and TNFalpha levels and reduced the myocardial reperfusion injury in patients with acute myocardial infarction, after percutaneous coronary intervention (PCI) [193]. The level of plasma ET-1, sP-sel, and hs-CRP following treatment with DHI indicated that it could inhibit platelet activation and inflammation, and angiogenesis and protect the endothelial function in patients with acute coronary syndrome (ACS) after PCI [194-198]. 
4.4. Antioxidant Effect on Liver Diseases. DSI was effective in the treatment of liver cirrhosis and fibrosis due to chronic hepatitis B virus infection [199-201], and intrahepatic cholestasis (ICP) by inhibiting ROS production [202].

$\mathrm{XBJ}$ prevented the release of serum proinflammatory cytokines, thereby alleviating hepatic I/R injury and promoting the recovery of intestinal function, but it did not demonstrate a protective effect on coagulopathy [203].

4.5. Antioxidant Effect on Cancer. Treatment with ASI significantly improved the activity of human tumor necrosis factor-beta (TNF-beta) and the levels of $\operatorname{IgA}, \operatorname{IgG}$, and $\operatorname{IgM}$, as well as the activity of natural killer (NK) cells in patients with lung cancer [204].

4.6. Antioxidant Effect on Other Diseases. When critically ill patients with severe community-acquired pneumonia were given XBJ, there was a significant improvement in the pneumonia severity index, primary end points, secondary clinical outcomes of mortality, and duration of mechanical ventilation and ICU stay [205].

When COVID-19 patients were treated with XBJ, the inflammatory markers such as white blood cell count, lymphocyte count, C-reactive protein level, and erythrocyte sedimentation rate significantly increased. The condition and prognosis of the patients improved [206]. XBJ is also effective in the treatment of patients with severe acute pancreatitis (SAP). It could decrease the incidence of complications, shorten the length of stay in hospitals, and reduce the mortality rate in SAP patients [207].

\section{Data Availability}

No data were used to support this study.

\section{Disclosure}

Shijun Zhang and Zhibo Gai are considered as the co-first authors.

\section{Conflicts of Interest}

The authors declare no conflicts of interest.

\section{Authors' Contributions}

Conceptualization, literature data search, and drafting of the manuscript were performed by S. Z., Z. G., T. G., J. C., Q. C., and Y. L.; manuscript correction and final approval were conducted by S. Z., Z. G., and Q. C. All authors have read and agreed to the published version of the manuscript.

\section{Acknowledgments}

This work was supported by the Natural Science Foundation of Shandong Province to Q.C. (ZR2020KH096) and by the Jinan Independent Innovation Team-Blood Circulation and Blood Vessel Reconstruction Innovation Team to Y.L. (2020GXRC017).

\section{References}

[1] B. Singh, J. P. Singh, A. Kaur, and N. Singh, "Phenolic composition and antioxidant potential of grain legume seeds: a review," Food Research International, vol. 101, pp. 1-16, 2017.

[2] C. Scholl, A. Lepper, T. Lehr et al., "Population nutrikinetics of green tea extract," PLoS One, vol. 13, no. 2, Article ID e0193074, 2018.

[3] S. Kakkar and S. Bais, "A review on protocatechuic Acid and its pharmacological potential," ISRN Pharmacology, vol. 2014, Article ID 952943, 2014.

[4] Y. Semaming, P. Pannengpetch, S. C. Chattipakorn, and N. Chattipakorn, "Pharmacological properties of protocatechuic Acid and its potential roles as complementary medicine," Evidence-Based Complementary and Alternative Medicine, vol. 2015, Article ID 593902, 2015.

[5] K. Krzysztoforska, D. Mirowska-Guzel, and E. Widy-Tyszkiewicz, "Pharmacological effects of protocatechuic acid and its therapeutic potential in neurodegenerative diseases: review on the basis of in vitro and in vivo studies in rodents and humans," Nutritional Neuroscience, vol. 22, no. 2, pp. 72-82, 2019.

[6] R. R. A. Kalsoom Khan, N. Fatima, S. Mahmood et al., "Pharmacological activities OF protocatechuic acid," Acta Poloniae Pharmaceutica, vol. 72, no. 4, pp. 643-650, 2015.

[7] N. Bhattacharjee, T. K. Dua, R. Khanra et al., "Protocatechuic acid, a phenolic from sansevieria roxburghiana leaves, suppresses diabetic cardiomyopathy via stimulating glucose metabolism, ameliorating oxidative stress, and inhibiting inflammation," Frontiers in Pharmacology, vol. 8, Article ID 251, 2017.

[8] P. Ormazabal, B. Scazzocchio, R. Varì et al., "Effect of protocatechuic acid on insulin responsiveness and inflammation in visceral adipose tissue from obese individuals: possible role for PTP1B," International Journal of Obesity, vol. 42, no. 12, pp. 2012-2021, 2018.

[9] L. Zhang, Y. Ji, Z. Kang, C. Lv, and W. Jiang, "Protocatechuic aldehyde ameliorates experimental pulmonary fibrosis by modulating HMGB1/RAGE pathway," Toxicology and Applied Pharmacology, vol. 283, no. 1, pp. 50-56, 2015.

[10] Y.-T. Chang, M.-C. Chung, C.-C. Hsieh, J.-J. Shieh, and W.-J. Wu, "Evaluation of the therapeutic effects of protocatechuic aldehyde in diabetic nephropathy," Toxins, vol. 13, no. 8 , p. 560,2021 .

[11] G. Wei, Y. Guan, Y. Yin et al., "Anti-inflammatory effect of protocatechuic aldehyde on myocardial ischemia/reperfusion injury in vivo and in vitro," Inflammation, vol. 36, no. 3, pp. 592-602, 2013.

[12] Z.-Q. Chang, E. Gebru, S.-P. Lee et al., "In vitro antioxidant and anti-inflammatory activities of protocatechualdehyde isolated from Phellinus gilvus," Journal of Nutritional Science and Vitaminology, vol. 57, no. 1, pp. 118-122, 2011.

[13] Y.-L. Xing, Z. Zhou, Agula et al., "Protocatechuic aldehyde inhibits lipopolysaccharide-induced human umbilical vein endothelial cell apoptosis via regulation of caspase-3," Phytotherapy Research, vol. 26, no. 9, pp. 1334-1341, 2012.

[14] Y. Xu, W.-L. Jiang, S.-P. Zhang, H.-B. Zhu, and J. Hou, "Protocatechuic aldehyde protects against experimental sepsis in vitro and in vivo," Basic and Clinical Pharmacology and Toxicology, vol. 110, no. 4, pp. 384-389, 2012.

[15] C. Y. Moon, C. R. Ku, Y. H. Cho, and E. J. Lee, "Protocatechuic aldehyde inhibits migration and proliferation of vascular smooth muscle cells and intravascular thrombosis," 
Biochemical and Biophysical Research Communications, vol. 423, no. 1, pp. 116-121, 2012.

[16] A. R. Kho, B. Y. Choi, S. H. Lee et al., "Effects of protocatechuic acid (PCA) on global cerebral ischemia-induced hippocampal neuronal death," International Journal of Molecular Sciences, vol. 19, no. 5, 2018.

[17] Y. Shao and J. Bao, "Polyphenols in whole rice grain: genetic diversity and health benefits," Food Chemistry, vol. 180, pp. 86-97, 2015.

[18] S. Tian, K. Nakamura, T. Cui, and H. Kayahara, "Highperformance liquid chromatographic determination of phenolic compounds in rice," Journal of Chromatography A, vol. 1063, no. 1-2, pp. 121-128, 2005.

[19] Y.-P. Huang and H.-M. Lai, "Bioactive compounds and antioxidative activity of colored rice bran," Journal of Food and Drug Analysis, vol. 24, no. 3, pp. 564-574, 2016.

[20] B. Xu and S. K. C. Chang, "Phenolic substance characterization and chemical and cell-based antioxidant activities of 11 lentils grown in the northern United States," Journal of Agricultural and Food Chemistry, vol. 58, no. 3, pp. 15091517, 2010.

[21] S. Multari, M. Neacsu, L. Scobbie et al., "Nutritional and phytochemical content of high-protein crops," Journal of Agricultural and Food Chemistry, vol. 64, no. 41, pp. 78007811, 2016.

[22] T. N. Ly, C. Hazama, M. Shimoyamada, H. Ando, K. Kato, and R. Yamauchi, "Antioxidative compounds from the outer scales of onion," Journal of Agricultural and Food Chemistry, vol. 53, no. 21, pp. 8183-8189, 2005.

[23] I. Fecka and S. Turek, "Determination of water-soluble polyphenolic compounds in commercial herbal teas from Lamiaceae: peppermint, melissa, and sage," Journal of Agricultural and Food Chemistry, vol. 55, no. 26, pp. 1090810917, 2007.

[24] C. Jayasinghe, N. Gotoh, T. Aoki, and S. Wada, "Phenolics composition and antioxidant activity of sweet basil (Ocimum basilicum L.)," Journal of Agricultural and Food Chemistry, vol. 51, no. 15, pp. 4442-4449, 2003.

[25] M. Kivilompolo and T. Hyötyläinen, "On-line coupled dynamic sonication-assisted extraction-liquid chromatography for the determination of phenolic acids in Lamiaceae herbs," Journal of Chromatography A, vol. 1216, no. 6, pp. 892-896, 2009.

[26] J. B. Park, "Identification and quantification of a major antioxidant and anti-inflammatory phenolic compound found in basil, lemon thyme, mint, oregano, rosemary, sage, and thyme," International Journal of Food Sciences and Nutrition, vol. 62, no. 6, pp. 577-584, 2011.

[27] H. Kikuzaki, S.-i. Kayano, N. Fukutsuka, T. Mitani, and N. Nakatani, "Antioxidant activity of prune (Prunus domestica L.) constituents and a new synergist," Journal of Agricultural and Food Chemistry, vol. 50, no. 13, pp. 37083712, 2002.

[28] R. Wang, L. Wang, S. Yuan et al., "Compositional modifications of bioactive compounds and changes in the edible quality and antioxidant activity of 'Friar' plum fruit during flesh reddening at intermediate temperatures," Food Chemistry, vol. 254, pp. 26-35, 2018.

[29] Q. Liu, G. Y. Tang, C. N. Zhao et al., "Comparison of antioxidant activities of different grape varieties," Molecules, vol. 23, no. 10, 2018.

[30] J. Orsavová, I. Hlaváčová, J. Mlček, L. Snopek, and L. Mišurcová, "Contribution of phenolic compounds, ascorbic acid and vitamin $\mathrm{E}$ to antioxidant activity of currant
(Ribes L.) and gooseberry (Ribes uva-crispa L.) fruits," Food Chemistry, vol. 284, pp. 323-333, 2019.

[31] M. R. Loizzo, D. Pacetti, P. Lucci et al., "Prunus persica var. platycarpa (tabacchiera peach): bioactive compounds and antioxidant activity of pulp, peel and seed ethanolic extracts," Plant Foods for Human Nutrition, vol. 70, no. 3, pp. 331-337, 2015.

[32] S. Sang, K. Lapsley, W.-S. Jeong, P. A. Lachance, C.-T. Ho, and R. T. Rosen, "Antioxidative phenolic compounds isolated from almond skins (Prunus amygdalusBatsch)," Journal of Agricultural and Food Chemistry, vol. 50, no. 8, pp. 2459-2463, 2002.

[33] J. Oracz, E. Nebesny, and D. Żyżelewicz, "Identification and quantification of free and bound phenolic compounds contained in the high-molecular weight melanoidin fractions derived from two different types of cocoa beans by UHPLCDAD-ESI-HR-MSn," Food Research International, vol. 115, pp. 135-149, 2019.

[34] J. Choi, X. Jiang, J. B. Jeong, and S.-H. Lee, “Anticancer activity of protocatechualdehyde in human breast cancer cells," Journal of Medicinal Food, vol. 17, no. 8, pp. 842-848, 2014.

[35] I. Da-Costa-Rocha, B. Bonnlaender, H. Sievers, I. Pischel, and M. Heinrich, "Hibiscus sabdariffa L. - a phytochemical and pharmacological review," Food Chemistry, vol. 165, pp. 424-443, 2014.

[36] M.-J. Lee, F.-P. Chou, T.-H. Tseng, M.-H. Hsieh, M.-C. Lin, and C.-J. Wang, "Hibiscus protocatechuic acid or esculetin can inhibit oxidative LDL induced by either copper ion or nitric oxide donor," Journal of Agricultural and Food Chemistry, vol. 50, no. 7, pp. 2130-2136, 2002.

[37] W. L. Lin, Y. J. Hsieh, F. P. Chou, C. J. Wang, M. T. Cheng, and T. H. Tseng, "Hibiscus protocatechuic acid inhibits lipopolysaccharide-induced rat hepatic damage," Archives of Toxicology, vol. 77, no. 1, pp. 42-47, 2003.

[38] A. I. Hartstein, V. Morthland, T. A. Golper, and A. L. Rashad, "Ciprofloxacin and plasmids in staphylococci," Journal of Antimicrobial Chemotherapy, vol. 27, no. 1, pp. 141-144, 1991.

[39] S. S. Nambiar, K. S. Venugopal, N. P. Shetty, and K. A. A. Appaiah, "Fermentation induced changes in bioactive properties of wine from Phyllanthus with respect to atherosclerosis," Journal of Food Science and Technology, vol. 53, no. 5, pp. 2361-2371, 2016.

[40] R. Abu-Amsha, K. D. Croft, I. B. Puddey, J. M. Proudfoot, and L. J. Beilin, "Phenolic content of various beverages determines the extent of inhibition of human serum and low-density lipoprotein oxidation in vitro: identification and mechanism of action of some cinnamic acid derivatives from red wine," Clinical Science, vol. 91, no. 4, pp. 449-458, 1996.

[41] M. Ellnain-Wojtaszek, "Phenolic acids from Ginkgo biloba L. Part I. Qualitative analysis of free and liberated by hydrolysis phenolic acids," Acta Poloniae Pharmaceutica, vol. 54, no. 3, pp. 225-228, 1997.

[42] M. Ellnain-Wojtaszek, "Phenolic acids from Ginkgo biloba L. Part II. Quantitative analysis of free and liberated by hydrolysis phenolic acids," Acta Poloniae Pharmaceutica, vol. 54, no. 3, pp. 229-232, 1997.

[43] M. Ellnain-Wojtaszek, Z. Kruczyński, and J. Kasprzak, "Investigation of the free radical scavenging activity of Ginkgo biloba L. leaves," Fitoterapia, vol. 74, no. 1-2, pp. 1-6, 2003.

[44] C. Sarikurkcu, M. Locatelli, A. Tartaglia et al., "Enzyme and biological activities of the water extracts from the plants 
aesculus hippocastanum, olea europaea and Hypericum perforatum that are used as folk remedies in Turkey," Molecules, vol. 25, no. 5, 2020.

[45] T.-T. Shih, H.-L. Lee, S.-C. Chen, C.-Y. Kang, R.-S. Shen, and Y.-A. Su, "Rapid analysis of traditional Chinese medicinePinellia ternataby microchip electrophoresis with electrochemical detection," Journal of Separation Science, vol. 41, no. 3, pp. 740-746, 2018.

[46] H. Q. Zhang, H. Yan, D. W. Qian et al., "Analysis and evaluation of eight active ingredients in Lilium lancifolium from different regions," Zhongguo Zhongyao Zazhi, vol. 42, no. 2, pp. 311-318, 2017.

[47] R. Tao, L. Miao, X. Yu et al., "Cynomorium songaricum Rupr demonstrates phytoestrogenic or phytoandrogenic like activities that attenuates benign prostatic hyperplasia via regulating steroid 5- $\alpha$-reductase," Journal of Ethnopharmacology, vol. 235, pp. 65-74, 2019.

[48] Y. S. Lee, Y.-H. Kang, J.-Y. Jung et al., "Inhibitory constituents of aldose reductase in the fruiting body of Phellinus linteus," Biological and Pharmaceutical Bulletin, vol. 31, no. 4, pp. 765-768, 2008.

[49] J. Cao, Y.-J. Wei, L.-W. Qi et al., "Determination of fifteen bioactive components in Radix et Rhizoma Salviae Miltiorrhizae by high-performance liquid chromatography with ultraviolet and mass spectrometric detection," Biomedical Chromatography, vol. 22, no. 2, pp. 164-172, 2008.

[50] L.-N. Zhou, X. Zhang, W.-Z. Xu et al., "Studies on the stability of salvianolic acid B as potential drug material," Phytochemical Analysis, vol. 22, no. 4, pp. 378-384, 2011.

[51] D. T. Ju, W. W. Kuo, T. J. Ho et al., "Protocatechuic acid from Alpinia oxyphylla induces schwann cell migration via ERK1/2, JNK and p38 activation," The American Journal of Chinese Medicine, vol. 43, no. 4, pp. 653-665, 2015.

[52] Z. J. Qing, W. Yong, L. Y. Hui et al., "Two new natural products from the fruits of Alpinia oxyphylla with inhibitory effects on nitric oxide production in lipopolysaccharideactivated RAW264.7 macrophage cells," Archives of Pharmacal Research, vol. 35, no. 12, pp. 2143-2146, 2012.

[53] M. Noguer, A. B. Cerezo, M. Rentzsch, P. Winterhalter, A. M. Troncoso, and M. C. García-Parrilla, "Simulated digestion and antioxidant activity of red wine fractions separated by high speed countercurrent chromatography," Journal of Agricultural and Food Chemistry, vol. 56, no. 19, pp. 8879-8884, 2008.

[54] G. Rocchetti, L. Lucini, G. Giuberti et al., "Transformation of polyphenols found in pigmented gluten-free flours during in vitro large intestinal fermentation," Food Chemistry, vol. 298, Article ID 125068, 2019.

[55] G. Rocchetti, S. R. Bhumireddy, G. Giuberti, R. Mandal, L. Lucini, and D. S. Wishart, "Edible nuts deliver polyphenols and their transformation products to the large intestine: an in vitro fermentation model combining targeted/ untargeted metabolomics," Food Research International, vol. 116, pp. 786-794, 2019.

[56] E. Marta Kuskoski, J. Martín, M. José Navas, and A. G. Asuero, "Antioxidant capacity of anthocyanin pigments," Flavonoids-From Biosynthesis to Human Health, Chapter 11, pp. 205-255, IntechOpen, London, UK, 2017.

[57] A. N. Winter and P. C. Bickford, "Anthocyanins and their metabolites as therapeutic agents for neurodegenerative disease," Antioxidants, vol. 8, no. 9, 2019.

[58] X. Wang, K. Yan, X. Ma et al., "Simultaneous determination and pharmacokinetic study of protocatechuic aldehyde and its major active metabolite protocatechuic acid in rat plasma by liquid chromatography-tandem mass spectrometry," Journal of Chromatographic Science, vol. 54, no. 5, pp. 697-705, 2016.

[59] M. Xu, Z. Zhang, G. Fu et al., "Liquid chromatographytandem mass spectrometry analysis of protocatechuic aldehyde and its phase I and II metabolites in rat," Journal of Chromatography B, vol. 856, no. 1-2, pp. 100-107, 2007.

[60] P.-H. Chen, Y.-M. Weng, Z.-R. Yu, M. Koo, and B.-J. Wang, "Extraction temperature affects the activities of antioxidation, carbohydrate-digestion enzymes, and angiotensin-converting enzyme of Pleurotus citrinopileatus extract," Journal of Food and Drug Analysis, vol. 24, no. 3, pp. 548$555,2016$.

[61] S.-W. Min, S.-N. Ryu, and D.-H. Kim, “Anti-inflammatory effects of black rice, cyanidin-3-O- $\beta$-d-glycoside, and its metabolites, cyanidin and protocatechuic acid," International Immunopharmacology, vol. 10, no. 8, pp. 959-966, 2010.

[62] I. Sedej, M. Sakač, A. Mandić, A. Mišan, V. Tumbas, and J. Čanadanović-Brunet, "Buckwheat (fagopyrum esculentumMoench) grain and fractions: antioxidant compounds and activities," Journal of Food Science, vol. 77, no. 9, pp. C954-C959, 2012.

[63] B. Stodolak, A. Starzyńska-Janiszewska, M. Mika, and A. Wikiera, "Rhizopus oligosporus and Co-fermentation as a tool for increasing the antioxidant potential of grass pea and flaxseed oil-cake tempe," Molecules, vol. 25, no. 20, 2020.

[64] J. A. Gutiérrez-Uribe, I. Romo-Lopez, and S. O. SernaSaldívar, "Phenolic composition and mammary cancer cell inhibition of extracts of whole cowpeas (Vigna unguiculata) and its anatomical parts," Journal of Functional Foods, vol. 3, no. 4, pp. 290-297, 2011.

[65] S. C. Q. Magalhães, M. Taveira, A. R. J. Cabrita, A. J. M. Fonseca, P. Valentão, and P. B. Andrade, "European marketable grain legume seeds: further insight into phenolic compounds profiles," Food Chemistry, vol. 215, pp. 177-184, 2017.

[66] Y.-K. Wang, X. Zhang, G.-L. Chen, J. Yu, L.-Q. Yang, and Y.-Q. Gao, "Antioxidant property and their free, soluble conjugate and insoluble-bound phenolic contents in selected beans," Journal of Functional Foods, vol. 24, pp. 359-372, 2016.

[67] N. Arslan Burnaz, M. Küçük, and Z. Akar, "An on-line HPLC system for detection of antioxidant compounds in some plant extracts by comparing three different methods," Journal of Chromatography B, vol. 1052, pp. 66-72, 2017.

[68] W. Li, X. Wang, J. Zhang et al., "Multivariate analysis illuminates the effects of vacuum drying on the extractable and nonextractable polyphenols profile of loquat fruit," Journal of Food Science, vol. 84, no. 4, pp. 726-737, 2019.

[69] J. P. Singh, A. Kaur, K. Shevkani, and N. Singh, "Composition, bioactive compounds and antioxidant activity of common Indian fruits and vegetables," Journal of Food Science \& Technology, vol. 53, no. 11, pp. 4056-4066, 2016.

[70] R. B. Rodrigues, R. Lichtenthäler, B. F. Zimmermann et al., "Total oxidant scavenging capacity of euterpe oleracea mart. (Açaí) seeds and identification of their polyphenolic compounds," Journal of Agricultural and Food Chemistry, vol. 54, no. 12, pp. 4162-4167, 2006.

[71] K. Lapsley, S. Sang, R. T. Rosen, and C.-T. Ho, "New prenylated benzoic acid and other constituents from almond hulls (Prunus amygdalus Batsch)," Journal of Agricultural and Food Chemistry, vol. 50, no. 3, pp. 607-609, 2002. 
[72] L. A. de la Rosa, E. Alvarez-Parrilla, and F. Shahidi, "Phenolic compounds and antioxidant activity of kernels and shells of Mexican pecan (Carya illinoinensis)," Journal of Agricultural and Food Chemistry, vol. 59, no. 1, pp. 152-162, 2011.

[73] Z.-y. Qu, Y.-w. Zhang, S.-w. Zheng et al., "A new phenylethanoid glycoside fromOrobanche cernuaLoefling," Natural Product Research, vol. 30, no. 8, pp. 948-953, 2016.

[74] L. J. An, S. Guan, G. F. Shi, Y. M. Bao, Y. L. Duan, and B. Jiang, "Protocatechuic acid from Alpinia oxyphylla against MPP+-induced neurotoxicity in PC12 cells," Food and Chemical Toxicology, vol. 44, no. 3, pp. 436-443, 2006.

[75] Y. Qi, X. Cheng, H. Jing et al., "Comparative pharmacokinetic study of the components in Alpinia oxyphylla Miq.Schisandra chinensis (Turcz.) Baill. herb pair and its single herb between normal and Alzheimer's disease rats by UPLCMS/MS," Journal of Pharmaceutical and Biomedical Analysis, vol. 177, Article ID 112874, 2020.

[76] S.-H. Ko, S.-W. Choi, S.-K. Ye, S. Yoo, H.-S. Kim, and M.-H. Chung, "Comparison of anti-oxidant activities of seventy herbs that have been used in Korean traditional medicine," Nutrition Research and Practice, vol. 2, no. 3, pp. 143-151, 2008.

[77] K. Liang, S. Cui, Q. Zhang, B. Kaishun, Q. Zhongzhi, and J. Ying, "UPLC simultaneous determination of five active components in Cinnamomi Ramulus," Zhongguo Zhongyao Zazhi, vol. 36, no. 23, pp. 3298-3301, 2011.

[78] G. K. Jayaprakasha, M. Ohnishi-Kameyama, H. Ono, M. Yoshida, and L. Jaganmohan Rao, "Phenolic constituents in the fruits of Cinnamomum zeylanicum and their antioxidant activity," Journal of Agricultural and Food Chemistry, vol. 54, no. 5, pp. 1672-1679, 2006.

[79] S. Lee, S. H. Shim, J. S. Kim, K. H. Shin, and S. S. Kang, "Aldose reductase inhibitors from the fruiting bodies of Ganoderma applanatum," Biological and Pharmaceutical Bulletin, vol. 28, no. 6, pp. 1103-1105, 2005.

[80] J. P. Xue, Y. Ding, A. M. Zhang, and C. Q. Hu, "The change of activity of protective enzyme around sprout tumble of Pinellia ternate under high temperature stress," Zhongguo Zhongyao Zazhi, vol. 29, no. 7, pp. 641-643, 2004.

[81] W. H. Feng, C. Li, W. M. Xin et al., "Exploration on feasibility of introducing bioassay method into quality evaluation of Chinese herbal medicines by studying on the correlation between antioxidant activity of Prunella vulgaris and its total phenolic acids content for example," Zhongguo Zhongyao Zazhi, vol. 41, no. 14, pp. 2660-2668, 2016.

[82] P. Nuntanakorn, B. Jiang, L. S. Einbond et al., "Polyphenolic constituents of Actaea racemosa," Journal of Natural Products, vol. 69, no. 3, pp. 314-318, 2006.

[83] Q. Cao, J. Li, Y. Xia et al., "Green extraction of six phenolic compounds from rattan (calamoideae faberii) with deep eutectic solvent by homogenate-assisted vacuum-cavitation method," Molecules, vol. 24, no. 1, 2018.

[84] X. Q. Zhao, S. Guo, H. Yan et al., "Analysis of phenolic acids and flavonoids in leaves of Lycium barbarum from different habitats by ultra-high-performance liquid chromatography coupled with triple quadrupole tandem mass spectrometry," Biomedical Chromatography, vol. 33, no. 8, Article ID e4552, 2019.

[85] L. Ding, H. M. Zhao, W. J. Zeng, L. Qing, Y. Wang, and S. Qing Wang, "Physiological responses of five plants in northwest China arid area under drought stress," Yingyong Shengtai Xuebao, vol. 28, no. 5, pp. 1455-1463, 2017.

[86] S. Prachayasittikul, P. Buraparuangsang, A. Worachartcheewan, C. Isarankura-Na-Ayudhya,
S. Ruchirawat, and V. Prachayasittikul, "Antimicrobial and antioxidative activities of bioactive constituents from Hydnophytum formicarum Jack," Molecules, vol. 13, no. 4, pp. 904-921, 2008.

[87] S. T. S. Hassan and E. Švajdlenka, "Biological evaluation and molecular docking of protocatechuic acid from Hibiscus sabdariffa L. As a potent urease inhibitor by an ESI-MS based method," Molecules, vol. 22, no. 10, 2017.

[88] C.-L. Liu, J.-M. Wang, C.-Y. Chu, M.-T. Cheng, and T.-H. Tseng, "In vivo protective effect of protocatechuic acid on tert-butyl hydroperoxide-induced rat hepatotoxicity," Food and Chemical Toxicology, vol. 40, no. 5, pp. 635-641, 2002.

[89] H. Etoh, K. Murakami, T. Yogoh, H. Ishikawa, Y. Fukuyama, and H. Tanaka, "Anti-oxidative compounds in barley tea," Bioscience Biotechnology and Biochemistry, vol. 68, no. 12, pp. 2616-2618, 2004.

[90] A. T. Dinkova-Kostova and P. Talalay, "Direct and indirect antioxidant properties of inducers of cytoprotective proteins," Molecular Nutrition \& Food Research, vol. 52, no. 1, pp. S128-S138, 2008.

[91] Y. Semaming, J. Sripetchwandee, P. Sa-Nguanmoo et al., "Protocatechuic acid protects brain mitochondrial function in streptozotocin-induced diabetic rats," Applied Physiology Nutrition and Metabolism, vol. 40, no. 10, pp. 1078-1081, 2015.

[92] S. Stanga, A. Caretto, M. Boido, and A. Vercelli, "Mitochondrial dysfunctions: a red thread across neurodegenerative diseases," International Journal of Molecular Sciences, vol. 21, no. 10, 2020 .

[93] X. Yin, X. Zhang, C. Lv et al., "Protocatechuic acid ameliorates neurocognitive functions impairment induced by chronic intermittent hypoxia," Scientific Reports, vol. 5, no. 1, Article ID 14507, 2015.

[94] Z. Zhong, X. Yao, M. Luo et al., "Protocatechuic aldehyde mitigates hydrogen peroxide-triggered PC12 cell damage by down-regulating MEG3," Artificial Cells, Nanomedicine, and Biotechnology, vol. 48, no. 1, pp. 602-609, 2020.

[95] J.-W. Gao, T. Yamane, H. Maita et al., "DJ-1-Mediated protective effect of protocatechuic aldehyde against oxidative stress in SH-SY5Y cells," Journal of Pharmacological Sciences, vol. 115, no. 1, pp. 36-44, 2011.

[96] C. Vassalle, M. Maltinti, and L. Sabatino, "Targeting oxidative stress for disease prevention and therapy: where do we stand, and where do we go from here," Molecules, vol. 25, no. 11, 2020.

[97] G. Veurink, G. Perry, and S. K. Singh, "Role of antioxidants and a nutrient rich diet in Alzheimer's disease," Open Biology, vol. 10, no. 6, Article ID 200084, 2020.

[98] L. Chen, H. Huang, G. Mao et al., "The 2019 yearbook of Neurorestoratology," Journal of Neurorestoratology, vol. 8, no. 1, pp. 1-11, 2020.

[99] R. Masella, C. Santangelo, M. D’Archivio, G. LiVolti, C. Giovannini, and F. Galvano, "Protocatechuic acid and human disease prevention: biological activities and molecular mechanisms," Current Medicinal Chemistry, vol. 19, no. 18, pp. 2901-2917, 2012.

[100] X. Zhao, S. Zhai, M.-S. An et al., "Neuroprotective effects of protocatechuic aldehyde against neurotoxin-induced cellular and animal models of Parkinson's disease," PLoS One, vol. 8, no. 10, Article ID e78220, 2013.

[101] C. Guo, J. Zhu, J. Wang et al., "Neuroprotective effects of protocatechuic aldehyde through PLK2/p-GSK3 $\beta / \mathrm{Nrf} 2$ signaling pathway in both in vivo and in vitro models of 
Parkinson's disease," Aging, vol. 11, no. 21, pp. 9424-9441, 2019.

[102] Z. Zhang, G. Li, S. S. W. Szeto et al., "Examining the neuroprotective effects of protocatechuic acid and chrysin on in vitro and in vivo models of Parkinson disease," Free Radical Biology and Medicine, vol. 84, pp. 331-343, 2015.

[103] R. Hornedo-Ortega, M. A. Álvarez-Fernández, A. B. Cerezo, T. Richard, A. M. Troncoso, and M. C. Garcia-Parrilla, "Protocatechuic acid: inhibition of fibril formation, destabilization of preformed fibrils of amyloid- $\beta$ and $\alpha$-synuclein, and neuroprotection," Journal of Agricultural and Food Chemistry, vol. 64, no. 41, pp. 7722-7732, 2016.

[104] C. Guo, S. Wang, J. Duan et al., "Protocatechualdehyde protects against cerebral ischemia-reperfusion-induced oxidative injury via protein kinase $c \varepsilon / n r f 2 / H O-1$ pathway," Molecular Neurobiology, vol. 54, no. 2, pp. 833-845, 2017.

[105] Z. Xi, X. Hu, X. Chen et al., "Protocatechuic acid exerts protective effects via suppression of the P38/JNK- NF- $\kappa B$ signalling pathway in an experimental mouse model of intracerebral haemorrhage," European Journal of Pharmacology, vol. 854, pp. 128-138, 2019.

[106] V. N. Thakare, V. D. Dhakane, and B. M. Patel, "Attenuation of acute restraint stress-induced depressive like behavior and hippocampal alterations with protocatechuic acid treatment in mice," Metabolic Brain Disease, vol. 32, no. 2, pp. 401-413, 2017.

[107] I. A. Adedara, O. B. Fasina, M. F. Ayeni, O. M. Ajayi, and E. O. Farombi, "Protocatechuic acid ameliorates neurobehavioral deficits via suppression of oxidative damage, inflammation, caspase- 3 and acetylcholinesterase activities in diabetic rats," Food and Chemical Toxicology, vol. 125, pp. 170-181, 2019.

[108] E. M. Al Olayan, A. S. Aloufi, O. D. AlAmri, O. H. El-Habit, and A. E. Abdel Moneim, "Protocatechuic acid mitigates cadmium-induced neurotoxicity in rats: role of oxidative stress, inflammation and apoptosis," The Science of the Total Environment, vol. 723, Article ID 137969, 2020.

[109] J. Wang, Y. Song, Z. Chen, and S. X. Leng, "Connection between systemic inflammation and neuroinflammation underlies neuroprotective mechanism of several phytochemicals in neurodegenerative diseases," Oxidative Medicine and Cellular Longevity, vol. 2018, Article ID 1972714, 2018.

[110] A. N. Winter, M. C. Brenner, N. Punessen et al., "Comparison of the neuroprotective and anti-inflammatory effects of the anthocyanin metabolites, protocatechuic acid and 4hydroxybenzoic acid," Oxidative Medicine and Cellular Longevity, vol. 2017, Article ID 6297080, 2017.

[111] S. Guan, D. Ge, T.-Q. Liu, X.-H. Ma, and Z.-F. Cui, "Protocatechuic acid promotes cell proliferation and reduces basal apoptosis in cultured neural stem cells," Toxicology in Vitro, vol. 23, no. 2, pp. 201-208, 2009.

[112] S. Guan, X. L. Zhang, D. Ge, T. Q. Liu, X. H. Ma, and Z. F. Cui, "Protocatechuic acid promotes the neuronal differentiation and facilitates survival of phenotypes differentiated from cultured neural stem and progenitor cells," European Journal of Pharmacology, vol. 670, no. 2-3, pp. 471-478, 2011.

[113] S.-j. Tsai and M.-c. Yin, "Anti-glycative and anti-inflammatory effects of protocatechuic acid in brain of mice treated by D-galactose," Food and Chemical Toxicology, vol. 50, no. 9, pp. 3198-3205, 2012.

[114] Y. Song, T. Cui, N. Xie, X. Zhang, Z. Qian, and J. Liu, "Protocatechuic acid improves cognitive deficits and attenuates amyloid deposits, inflammatory response in aged $\mathrm{A} \beta \mathrm{PP} / \mathrm{PS} 1$ double transgenic mice," International Immunopharmacology, vol. 20, no. 1, pp. 276-281, 2014.

[115] Z. Wang, X. Pan, D. Wang et al., "Protective effects of protocatechuic acid on retinal ganglion cells from oxidative damage induced by $\mathrm{H}_{2} \mathrm{O}_{2}$," Neurological Research, vol. 37, no. 2, pp. 159-166, 2015.

[116] S. Guan, B. Jiang, Y. M. Bao, and L. J. An, "Protocatechuic acid suppresses MPP+-induced mitochondrial dysfunction and apoptotic cell death in PC12 cells," Food and Chemical Toxicology, vol. 44, no. 10, pp. 1659-1666, 2006.

[117] M. M. Muley, V. N. Thakare, R. R. Patil, P. A. Bafna, and S. R. Naik, "Amelioration of cognitive, motor and endogenous defense functions with silymarin, piracetam and protocatechuic acid in the cerebral global ischemic rat model," Life Sciences, vol. 93, no. 1, pp. 51-57, 2013.

[118] G.-F. Shi, L.-J. An, B. Jiang, S. Guan, and Y.-M. Bao, “Alpinia protocatechuic acid protects against oxidative damage in vitro and reduces oxidative stress in vivo," Neuroscience Letters, vol. 403, no. 3, pp. 206-210, 2006.

[119] S. H. Lee, B. Y. Choi, A. R. Kho et al., "Protective effects of protocatechuic acid on seizure-induced neuronal death," International Journal of Molecular Sciences, vol. 19, no. 1, 2018.

[120] Y. S. Kim, H. W. Seo, M.-H. Lee, D. K. Kim, H. Jeon, and D. S. Cha, "Protocatechuic acid extends lifespan and increases stress resistance in Caenorhabditis elegans," Archives of Pharmacal Research, vol. 37, no. 2, pp. 245-252, 2014.

[121] V. N. Thakare, R. R. Patil, A. A. Suralkar, V. D. Dhakane, and B. M. Patel, "Protocatechuic acid attenuate depressive-like behavior in olfactory bulbectomized rat model: behavioral and neurobiochemical investigations," Metabolic Brain Disease, vol. 34, no. 3, pp. 775-787, 2019.

[122] V. N. Thakare, V. D. Dhakane, and B. M. Patel, "Potential antidepressant-like activity of silymarin in the acute restraint stress in mice: modulation of corticosterone and oxidative stress response in cerebral cortex and hippocampus," Pharmacological Reports, vol. 68, no. 5, pp. 1020-1027, 2016.

[123] V. N. Thakare, M. K. Aswar, Y. P. Kulkarni, R. R. Patil, and B. M. Patel, "Silymarin ameliorates experimentally induced depressive like behavior in rats: involvement of hippocampal BDNF signaling, inflammatory cytokines and oxidative stress response," Physiology \& Behavior, vol. 179, pp. 401-410, 2017.

[124] S. A. Adefegha, G. Oboh, O. S. Omojokun, and O. M. Adefegha, "Alterations of $\mathrm{Na}+/ \mathrm{K}+$-ATPase, cholinergic and antioxidant enzymes activity by protocatechuic acid in cadmium-induced neurotoxicity and oxidative stress in Wistar rats," Biomedicine \& Pharmacotherapy, vol. 83, pp. 559-568, 2016.

[125] R. D'Oria, R. Schipani, A. Leonardini et al., "The role of oxidative stress in cardiac disease: from physiological response to injury factor," Oxidative Medicine and Cellular Longevity, vol. 2020, Article ID 5732956, 2020.

[126] Y. Semaming, U. Kukongviriyapan, B. Kongyingyoes, W. Thukhammee, and P. Pannangpetch, "Protocatechuic acid restores vascular responses in rats with chronic diabetes induced by streptozotocin," Phytotherapy Research, vol. 30, no. 2, pp. 227-233, 2016.

[127] Y. Semaming, S. Kumfu, P. Pannangpetch, S. C. Chattipakorn, and N. Chattipakorn, "Protocatechuic acid exerts a cardioprotective effect in type 1 diabetic rats," Journal of Endocrinology, vol. 223, no. 1, pp. 13-23, 2014. 
[128] R. Harini and K. V. Pugalendi, "Antihyperglycemic effect of protocatechuic acid on streptozotocin-diabetic rats," Journal of Basic and Clinical Physiology and Pharmacology, vol. 21, no. 1, pp. 79-91, 2010.

[129] A. J. Rodríguez-Méndez, W. Carmen-Sandoval, C. LomasSoria et al., "Timbe (acaciella angustissima) pods extracts reduce the levels of glucose, insulin and improved physiological parameters, hypolipidemic effect, oxidative stress and renal damage in streptozotocin-induced diabetic rats," Molecules, vol. 23, no. 11, 2018.

[130] B. Scazzocchio, R. Varì, C. Filesi et al., "Cyanidin-3-O-glucoside and protocatechuic acid exert insulin-like effects by upregulating PPAR activity in human omental adipocytes," Diabetes, vol. 60, no. 9, pp. 2234-2244, 2011.

[131] B. Scazzocchio, R. Varì, C. Filesi et al., "Protocatechuic acid activates key components of insulin signaling pathway mimicking insulin activity," Molecular Nutrition \& Food Research, vol. 59, no. 8, pp. 1472-1481, 2015.

[132] Y. A. El-Sonbaty, G. M. Suddek, N. Megahed, and N. M. Gameil, "Protocatechuic acid exhibits hepatoprotective, vasculoprotective, antioxidant and insulin-like effects in dexamethasone-induced insulin-resistant rats," Biochimie, vol. 167, pp. 119-134, 2019.

[133] Y. S. Lee, Y.-H. Kang, J.-Y. Jung et al., "Protein glycation inhibitors from the fruiting body of Phellinus linteus," Biological and Pharmaceutical Bulletin, vol. 31, no. 10, pp. 1968-1972, 2008.

[134] M. Li, D. Yin, J. Li et al., "Rosmarinic acid, the active component of Salvia miltiorrhizae, improves gliquidone transport by regulating the expression and function of P-gp and BCRP in Caco-2 cells," Die Pharmazie, vol. 75, no. 1, pp. 18-22, 2020.

[135] Y. S. Kim, N. H. Kim, S. W. Lee, Y. M. Lee, D. S. Jang, and J. S. Kim, "Effect of protocatechualdehyde on receptor for advanced glycation end products and TGF- $\beta 1$ expression in human lens epithelial cells cultured under diabetic conditions and on lens opacity in streptozotocin-diabetic rats," European Journal of Pharmacology, vol. 569, no. 3, pp. 171-179, 2007.

[136] O. Ciftci, O. M. Disli, and N. Timurkaan, "Protective effects of protocatechuic acid on TCDD-induced oxidative and histopathological damage in the heart tissue of rats," Toxicology and Industrial Health, vol. 29, no. 9, pp. 806-811, 2013.

[137] X.-L. Tang, J.-X. Liu, W. Dong et al., "The cardioprotective effect of protocatechuic acid on myocardial ischemia/ reperfusion injury," Journal of Pharmacological Sciences, vol. 125, no. 2, pp. 176-183, 2014.

[138] R. Harini and K. V. Pugalendi, "Antioxidant and antihyperlipidaemic activity of protocatechuic acid on streptozotocindiabetic rats," Redox Report, vol. 15, no. 2, pp. 71-80, 2010.

[139] K. Masodsai, Y. Y. Lin, R. Chaunchaiyakul, C. T. Su, S. D. Lee, and A. L. Yang, "Twelve-week protocatechuic acid administration improves insulin-induced and insulin-like growth factor-1-induced vasorelaxation and antioxidant activities in aging spontaneously hypertensive rats," Nutrients, vol. 11, no. 3, 2019.

[140] L. Safaeian, V. Hajhashemi, S. Haghjoo Javanmard, and H. Sanaye Naderi, "The effect of protocatechuic acid on blood pressure and oxidative stress in glucocorticoid-induced hypertension in rat," Iranian Journal of Pharmaceutical Research, vol. 15, no. 1, pp. 83-91, 2016.
[141] X. Fang, Y. Liu, J. Lu et al., "Protocatechuic aldehyde protects against isoproterenol-induced cardiac hypertrophy via inhibition of the JAK2/STAT3 signaling pathway," NaunynSchmiedeberg's Archives of Pharmacology, vol. 391, no. 12, pp. 1373-1385, 2018.

[142] Y.-J. Wan, Q. Guo, D. Liu, Y. Jiang, K.-W. Zeng, and P.-F. Tu, "Protocatechualdehyde reduces myocardial fibrosis by directly targeting conformational dynamics of collagen," European Journal of Pharmacology, vol. 855, pp. 183-191, 2019.

[143] B. S. Kong, Y. H. Cho, and E. J. Lee, "G protein-coupled estrogen receptor-1 is involved in the protective effect of protocatechuic aldehyde against endothelial dysfunction," PLoS One, vol. 9, no. 11, Article ID e113242, 2014.

[144] N. H. Gay, K. Phopin, W. Suwanjang et al., "Neuroprotective effects of phenolic and carboxylic acids on oxidative stressinduced toxicity in human neuroblastoma SH-SY5Y cells," Neurochemical Research, vol. 43, no. 3, pp. 619-636, 2018.

[145] L. Han, Q. Yang, W. Ma, J. Li, L. Qu, and M. Wang, "Protocatechuic acid ameliorated palmitic-acid-induced oxidative damage in endothelial cells through activating endogenous antioxidant enzymes via an adenosine-monophosphate-activated-protein-kinase-dependent pathway," Journal of Agricultural and Food Chemistry, vol. 66, no. 40, pp. 10400-10409, 2018.

[146] L. Han, Q. Yang, J. Li et al., "Protocatechuic acid-ameliorated endothelial oxidative stress through regulating acetylation level via CD36/AMPK pathway," Journal of Agricultural and Food Chemistry, vol. 67, no. 25, pp. 7060-7072, 2019.

[147] R. Varì, B. Scazzocchio, C. Santangelo et al., "Protocatechuic acid prevents oxLDL-induced apoptosis by activating JNK/ Nrf2 survival signals in macrophages," Oxidative Medicine and Cellular Longevity, vol. 2015, Article ID 351827, 2015.

[148] L. Jiang, H. Zeng, L. Ni et al., "HIF-1 $\alpha$ preconditioning potentiates antioxidant activity in ischemic injury: the role of sequential administration of dihydrotanshinone I and protocatechuic aldehyde in cardioprotection," Antioxidants and Redox Signaling, vol. 31, no. 3, pp. 227-242, 2019.

[149] R. Fu, J. Zhou, R. Wang et al., "Protocatechuic acid-mediated miR-219a-5p activation inhibits the p66shc oxidant pathway to alleviate alcoholic liver injury," Oxidative Medicine and Cellular Longevity, vol. 2019, Article ID 3527809, 2019.

[150] R. Sun, X. Kang, Y. Zhao et al., "Sirtuin 3-mediated deacetylation of acyl- CoA synthetase family member 3 by protocatechuic acid attenuates non-alcoholic fatty liver disease," British Journal of Pharmacology, vol. 177, no. 18, pp. 4166-4180, 2020.

[151] L. Ma, G. Wang, Z. Chen et al., "Modulating the p66shc signaling pathway with protocatechuic acid protects the intestine from ischemia-reperfusion injury and alleviates secondary liver damage," TheScientificWorld Journal, vol. 2014, Article ID 387640, 2014.

[152] T. Radhiga, A. Sundaresan, P. Viswanathan, and K. V. Pugalendi, "Effect of protocatechuic acid on lipid profile and DNA damage in D-galactosamine-induced hepatotoxic rats," Journal of Basic and Clinical Physiology and Pharmacology, vol. 27, no. 5, pp. 505-514, 2016.

[153] S. A. Adefegha, O. S. Omojokun, and G. Oboh, "Modulatory effect of protocatechuic acid on cadmium induced nephrotoxicity and hepatoxicity in rats in vivo," SpringerPlus, vol. 4, no. 1, Article ID 619, 2015.

[154] Z. Zhou, Y. Zhang, X.-R. Ding et al., "Protocatechuic aldehyde inhibits hepatitis $B$ virus replication both in vitro and in vivo," Antiviral Research, vol. 74, no. 1, pp. 59-64, 2007. 
[155] F. Qiu, R. Zhang, J. Sun et al., "Inhibitory effects of seven components of danshen extract on catalytic activity of cytochrome P450 enzyme in human liver microsomes," Drug Metabolism and Disposition, vol. 36, no. 7, pp. 1308-1314, 2008.

[156] G.-T. Liu, T.-M. Zhang, B.-e. Wang, and Y.-W. Wang, "Protective action of seven natural phenolic compounds against peroxidative damage to biomembranes," Biochemical Pharmacology, vol. 43, no. 2, pp. 147-152, 1992.

[157] P. Vitaglione, G. Donnarumma, A. Napolitano et al., "Protocatechuic acid is the major human metabolite of cyanidin-glucosides," Journal of Nutrition, vol. 137, no. 9, pp. 2043-2048, 2007.

[158] T.-H. Tseng, T.-W. Kao, C.-Y. Chu, F.-P. Chou, W.-L. Lin, and C.-J. Wang, "Induction of apoptosis by hibiscus protocatechuic acid in human leukemia cells via reduction of retinoblastoma (RB) phosphorylation and Bcl-2 expression," Biochemical Pharmacology, vol. 60, no. 3, pp. 307-315, 2000.

[159] E. C. H. Yip, A. S. L. Chan, H. Pang, Y. K. Tam, and Y. H. Wong, "Protocatechuic acid induces cell death in HepG2 hepatocellular carcinoma cells through a c-Jun N-terminal kinase-dependent mechanism," Cell Biology and Toxicology, vol. 22, no. 4, pp. 293-302, 2006.

[160] D. S. Peiffer, N. P. Zimmerman, L.-S. Wang et al., "Chemoprevention of esophageal cancer with black raspberries, their component anthocyanins, and a major anthocyanin metabolite, protocatechuic acid," Cancer Prevention Research, vol. 7, no. 6, pp. 574-584, 2014.

[161] K.-J. Kim, M.-A. Kim, and J.-H. Jung, "Antitumor and antioxidant activity of protocatechualdehyde produced from Streptomyces lincolnensis M-20," Archives of Pharmacal Research, vol. 31, no. 12, pp. 1572-1577, 2008.

[162] J. B. Guttenplan, K.-M. Chen, Y.-W. Sun et al., "Effects of black raspberry extract and protocatechuic acid on carcinogen-DNA adducts and mutagenesis, and oxidative stress in rat and human oral cells," Cancer Prevention Research, vol. 9, no. 8, pp. 704-712, 2016.

[163] Z. Xie, Z. Guo, Y. Wang, J. Lei, and J. Yu, "Protocatechuic acid inhibits the growth of ovarian cancer cells by inducing apoptosis and autophagy," Phytotherapy Research, vol. 32, no. 11, pp. 2256-2263, 2018.

[164] L. Gao, W.-F. Wu, L. Dong et al., "Protocatechuic aldehyde attenuates cisplatin-induced acute kidney injury by suppressing nox-mediated oxidative stress and renal inflammation," Frontiers in Pharmacology, vol. 7, Article ID 479, 2016.

[165] A. Beytur, O. Ciftci, M. Aydin, O. Cakir, N. Timurkaan, and F. Yılmaz, "Protocatechuic acid prevents reproductive damage caused by 2,3,7,8-tetrachlorodibenzo-p-dioxin (TCDD) in male rats," Andrologia, vol. 44, no. 1, pp. 454-461, 2012.

[166] O. R. Molehin, A. A. Adeyanju, S. A. Adefegha, A. O. Oyeyemi, and K. A. Idowu, "Protective mechanisms of protocatechuic acid against doxorubicin-induced nephrotoxicity in rat model," Journal of Basic and Clinical Physiology and Pharmacology, vol. 30, no. 4, 2019.

[167] M. Yüksel, M. Yıldar, M. Başbuğ et al., "Does protocatechuic acid, a natural antioxidant, reduce renal ischemia reperfusion injury in rats?" Ulus Travma Acil Cerrahi Derg, vol. 23, no. 1, pp. 1-6, 2017.

[168] O. O. Akanni, S. E. Owumi, O. G. Olowofela, A. A. Adeyanju, O. J. Abiola, and O. A. Adaramoye, "Protocatechuic acid ameliorates testosterone-induced benign prostatic hyperplasia through the regulation of inflammation and oxidative stress in castrated rats," Journal of Biochemical and Molecular Toxicology, vol. 34, no. 8, Article ID e22502, 2020.

[169] X. Zhang, C. Li, J. Li, Y. Xu, S. Guan, and M. Zhao, "Protective effects of protocatechuic acid on acute lung injury induced by lipopolysaccharide in mice via p38MAPK and NF- $\kappa$ B signal pathways," International Immunopharmacology, vol. 26, no. 1, pp. 229-236, 2015.

[170] E. Yadav, D. Singh, P. Yadav, and A. Verma, "Attenuation of dermal wounds via downregulating oxidative stress and inflammatory markers by protocatechuic acid rich n-butanol fraction of Trianthema portulacastrum Linn. in wistar albino rats," Biomedicine \& Pharmacotherapy, vol. 96, pp. 86-97, 2017.

[171] T. O. Ajiboye, R. S. Habibu, K. Saidu et al., "Involvement of oxidative stress in protocatechuic acid-mediated bacterial lethality," Microbiology, vol. 6, no. 4, 2017.

[172] Y.-X. Wu, T.-y. Wu, B.-b. Xu et al., "Protocatechuic acid inhibits osteoclast differentiation and stimulates apoptosis in mature osteoclasts," Biomedicine \& Pharmacotherapy, vol. 82, pp. 399-405, 2016.

[173] J. Zhang, B. Fu, X. Chen, D. Chen, and H. Yang, "Protocatechuic acid attenuates anterior cruciate ligament transection-induced osteoarthritis by suppressing osteoclastogenesis," Experimental and Therapeutic Medicine, vol. 19, no. 1, pp. 232-240, 2020.

[174] J. Ameeramja and E. Perumal, "Protocatechuic acid methyl ester ameliorates fluoride toxicity in A549 cells," Food and Chemical Toxicology, vol. 109, no. Pt 2, pp. 941-950, 2017.

[175] X. Li, F. Du, W. Jia et al., "Simultaneous determination of eight Danshen polyphenols in rat plasma and its application to a comparative pharmacokinetic study of DanHong injection and Danshen injection," Journal of Separation Science, vol. 40, no. 7, pp. 1470-1481, 2017.

[176] Y. Zhang, F. Bao, Z. Zhao, X. Sun, W. Qi, and J. Xie, "The stability investigation of compound Danshen injection (a traditional medicine) with a new high-performance liquid chromatography method," Pharmacognosy Magazine, vol. 9, no. 36, pp. 338-343, 2013.

[177] X. J. Han, L. Feng, D. D. Zhang, and X. B. Jia, "Quality comparison andstructural characteristics of material basic composition of Danshen injection from different manufacturers," Zhongguo Zhongyao Zazhi, vol. 41, no. 3, pp. 427-432, 2016.

[178] Y. Li, Y. Cui, X. Zhao, J. Baoxiu, and Q. Yongxiu, "Capillary electrophoresis with field-enhanced stacking for determination of water-soluble active principles in Salvia miltiorrhiza var. miltiorrhiza f. alba," Zhongguo Zhongyao Zazhi, vol. 36, no. 11, pp. 1466-1470, 2011.

[179] J. Shen, K. Yang, C. Sun, and M. Zheng, "Analysis of active components in Salvia miltiorrhiza injection based on vascular endothelial cell protection," Acta Pharmaceutica, vol. 64, no. 3, pp. 325-334, 2014.

[180] B. Shi, Q. Li, Y. Feng et al., "Pharmacokinetics of 13 active components in a rat model of middle cerebral artery occlusion after intravenous injection of Radix Salviae miltiorrhizae - Lignum dalbergiae odoriferae prescription," Journal of Separation Science, vol. 43, no. 2, pp. 531-546, 2020.

[181] X. Li, C. Cheng, F. Wang et al., "Pharmacokinetics of catechols in human subjects intravenously receiving XueBijing injection, an emerging antiseptic herbal medicine," Drug Metabolism and Pharmacokinetics, vol. 31, no. 1, pp. 95-98, 2016. 
[182] Y. Xie, P. Wang, Y. Ruan, P. Shi, and H. Yao, "Qualitative and quantitative analysis of the major ingredients of a herbal preparation, Ciwujia injection by combination of HPLC-QTOF-MS, HPLC-TQ-MS/MS and UPLC-PDA," Current Pharmaceutical Analysis, vol. 15, no. 4, pp. 388-398, 2019.

[183] L. Song, H. J. Qu, and X. J. Zhang, "Effect of danhong injection on cerebral injury in patients undergoing coronary artery bypass graft operation with extracorporeal circulation," Zhongguo Zhong Xi Yi Jie He Za Zhi, vol. 28, no. 8, pp. 705-707, 2008.

[184] M. Sun, J.-J. Zhang, J.-Z. Shan et al., "Clinical observation of Danhong Injection (herbal TCM product from Radix Salviae miltiorrhizae and Flos Carthami tinctorii) in the treatment of traumatic intracranial hematoma," Phytomedicine, vol. 16, no. 8, pp. 683-689, 2009.

[185] L. Q. Min, L. Y. Dang, and W. Y. Ma, "Clinical study on effect and therapeutical mechanism of composite Salvia injection on acute cerebral infarction," Zhongguo Zhong Xi Yi Jie He Za Zhi, vol. 22, no. 5, pp. 353-355, 2002.

[186] K. Yang, G. Dong, Y. Tian, and J. Li, "Effects of compound Danshen injection combined with magnesium sulfate on serum MPO and hs-CRP in patients with severe preeclampsia," Experimental and Therapeutic Medicine, vol. 16, no. 1, pp. 167-170, 2018.

[187] H. X. Ni, S. S. Luo, and G. M. Shao, "Effect of Acanthopanax senticosus injection on plasma and urinary endothelin in early stage of diabetic nephropathy," Zhongguo Zhong Xi Yi Jie He Za Zhi, vol. 21, no. 2, pp. 105-107, 2001.

[188] H. N. Wu and H. Sun, "Study on clinical therapeutic effect of composite Salvia injection matched with Western medicine in treating diabetic foot," Zhongguo Zhong Xi Yi Jie He Za Zhi, vol. 23, no. 10, pp. 727-729, 2003.

[189] X. R. Guo, W. T. Zhang, X. H. Chen, and K. S. Bi, "Determination of danshensu and protocatechuic aldehyde in Guanxinning injection powder by RP-HPLC," Zhongguo Zhongyao Zazhi, vol. 31, no. 16, pp. 1328-1330, 2006.

[190] Y. Jia, S. W. Leung, M. Y. Lee, G. Cui, X. Huang, and F. Pan, "The efficacy of guanxinning injection in treating angina pectoris: systematic review and meta-analysis of randomized controlled trials," Evidence-Based Complementary and Alternative Medicine, vol. 2013, Article ID 282707, 2013.

[191] P. Q. Wang, D. D. Li, W. Dong et al., "Danhong injection in the treatment of chronic stable angina: study protocol for a randomized controlled trial," Trials, vol. 16, no. 1, Article ID 474, 2015.

[192] Z. Xia, J. Gu, D. M. Ansley, F. Xia, and J. Yu, "Antioxidant therapy with Salvia miltiorrhiza decreases plasma endothelin-1 and thromboxane B2 after cardiopulmonary bypass in patients with congenital heart disease," The Journal of Thoracic and Cardiovascular Surgery, vol. 126, no. 5, pp. 1404-1410, 2003.

[193] L. T. Ding, Y. G. Zhu, Z. Q. Gu, C. Liang-liang, P. Jing-liang, and L. Guo-zhong, "Effect of salvia miltiorrhiza and Ligustrazine injection on the early myocardial damage of patients with severe burn," Zhonghua Shaoshang Zazhi, vol. 28, no. 3, pp. 170-172, 2012.

[194] Z. Q. Chen, L. Hong, and H. Wang, "Effect of danhong injection on platelet activation and inflammatory factors in patients of acute coronary syndrome after intervention therapy," Zhongguo Zhong Xi Yi Jie He Za Zhi, vol. 29, no. 8, pp. 692-694, 2009.

[195] P. X. Zhao and S. Jiang, "Effect of danhong injection on ET-1, sP-sel, and hs-CRP in patients with acute coronary syndrome undergoing percutaneous coronary intervention,"
Zhongguo Zhong Xi Yi Jie He Za Zhi, vol. 31, no. 1, pp. 11-14, 2011.

[196] Y. Wu, G. Wei, J. Yu et al., "Danhong injection alleviates postoperative intra-abdominal adhesion in a rat model," Oxidative Medicine and Cellular Longevity, vol. 2019, Article ID 4591384, 2019.

[197] Y. Guan, Y. Yin, Y. R. Zhu et al., "Dissection of mechanisms of a Chinese medicinal formula: danhong injection therapy for myocardial ischemia/reperfusion injury in vivo and in vitro," Evidence-Based Complementary and Alternative Medicine, vol. 2013, Article ID 972370, 2013.

[198] J. Zhang, F. Guo, J. Wei et al., "An integrated approach to identify critical transcription factors in the protection against hydrogen peroxide-induced oxidative stress by Danhong injection," Free Radical Biology and Medicine, vol. 112, pp. 480-493, 2017.

[199] F. Ye, Y. Liu, G. Qiu, Z. Yingren, and L. Min, "Clinical study on treatment of cirrhosis by different dosages of salvia injection," Zhong Yao Cai, vol. 28, no. 9, pp. 850-854, 2005.

[200] S. F. She, X. Z. Huang, and G. D. Tong, "[Clinical study on treatment of liver fibrosis by different dosages of Salvia injection]," Zhongguo Zhong Xi Yi Jie He Za Zhi, vol. 24, no. 1, pp. 17-20, 2004.

[201] C. Zhu, H. Cao, X. Zhou et al., "Meta-analysis of the clinical value of danshen injection and huangqi injection in liver cirrhosis," Evidence-Based Complementary and Alternative Medicine, vol. 2013, Article ID 842824, 2013.

[202] J. Fang, W. L. Gou, and Q. L. Li, "Effect of integrative Chinese and Western medicine in treating pregnant women with intrahepatic cholestasis," Zhongguo Zhong Xi Yi Jie He Za Zhi, vol. 29, no. 10, pp. 869-871, 2009.

[203] J. Shen, X. J. Lin, B. K. Cui, C. Pei-dong, Z. Qiu-yao, and Z. Qing-yu, "The protective effect of Xuebijing injection pretreatment on hepatic ischemia reperfusion injury and coagulopathy after excision of liver cancer," Zhonghua Wei Zhong Bing Ji Jiu Yi Xue, vol. 25, no. 12, pp. 743-748, 2013.

[204] D. B. Huang, R. Z. Ran, and Z. F. Yu, "Effect of Acanthopanax senticosus injection on the activities of human tumor necrosis factor and natural killer cell in blood in the patients with lung cancer," Zhongguo Zhongyao Zazhi, vol. 30, no. 8, pp. 621-624, 2005.

[205] Y. Song, C. Yao, Y. Yao et al., "XueBijing injection versus placebo for critically ill patients with severe communityacquired pneumonia," Critical Care Medicine, vol. 47, no. 9, pp. e735-e743, 2019.

[206] L. Wen, Z. Zhou, D. Jiang, and K. Huang, "Effect of Xuebijing injection on inflammatory markers and disease outcome of coronavirus disease 2019," Zhonghua Wei Zhong Bing Ji Jiu Yi Xue, vol. 32, no. 4, pp. 426-429, 2020.

[207] R. Zheng, L. Zhang, R. Tian et al., "The effect of Xuebijing injection for severe acute pancreatitis: a Meta analysis," Zhonghua Wei Zhong Bing Ji Jiu Yi Xue, vol. 27, no. 8, pp. 682-686, 2015. 